\title{
An Efficacy Examination and Constitutional Critique of School Shaming
}

\author{
AMANDA HARMON COOLEY* \\ "I never learned hate at home, or shame. I had to go to school \\ for that." \\ -Dick Gregory ${ }^{1}$
}

\section{TABLE OF CONTENTS}

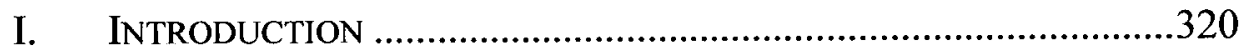

II. THE INEFFICACY AND HARM OF SCHOOL SHAMING PUNISHMENTS

A. School Shaming Punishments and Stigma A Definitional Framework.

B. Shaming Punishments-An Equally Ineffective and Harmful School Disciplinary Alternative

1. School Shaming Punishments Are Inefficacious

2. Shaming Punishments Inflict Substantial and Lasting Harm on Individual Students

3. Shaming Punishments Inflict Significant and

Enduring Community Collateral Consequences.

C. A Conclusion on the Efficacy Examination and Harm Analysis of School Shaming Punishments

III. A Constitutional CRitique of School Shaming

A. The Nature of Students' Constitutional Rights and

Judicial Deference to School Disciplinary Authority

B. School Shaming Punishments, Students' Constitutional

Rights, and 42 U.S.C. $\$ 1983$ Liability

1. Students' Constitutional Rights and 42 U.S.C. $\$ 1983$

Liability

2. School Shaming Punishments, Students' First Amendment Rights, and 42 U.S.C. $\S 1983$ Liability .......348

3. School Shaming Punishments, Students' Fourth Amendment Rights, and 42 U.S.C. $\S 1983$ Liability .......360

${ }^{*}$ Wayne Fisher Research Professor of Law, South Texas College of Law Houston. The author would like to thank her school for its research support and her colleagues for their feedback. She also extends her gratitude to Lauren Kosches and Jasmine Plott for their research assistance. A preliminary version of this Article was presented as a roundtable presentation at the 2016 Education Law Association Annual Conference.

${ }^{1}$ Dick Gregory, Shame, in EMERGING VOICES 285, 285 (Janet Madden-Simpson \& Sara M. Blake eds., 1990). 


\section{A Conclusion on the Constitutional Critique of School} Shaming Punishments ..........................................................371

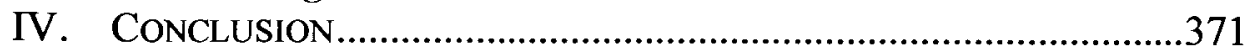

\section{INTRODUCTION}

According to her 42 U.S.C. $\S 1983$ lawsuit, a female seventh grade special education student in Republic, Missouri, was forced by school officials to personally apologize to the male student who had raped her on school grounds. ${ }^{2}$ School officials did not believe the child when she reported the on-campus rape and multiple sexual assaults to them. ${ }^{3}$ After being instructed to write the apology, the female student was also suspended. ${ }^{4}$ Upon her return to school, she was suspended again for disrespectful conduct and public display of affection after she accused the boy of raping her a second time. ${ }^{5} \mathrm{~A}$ subsequent medical examination confirmed the veracity of the girl's claims. ${ }^{6}$ The forced apology by the school was a shaming punishment that further victimized this young girl. ${ }^{7}$

According to another $\S 1983$ lawsuit, Jane Doe, a high school student in Harrisville, New York, was escorted to the principal's office upon her arrival at school, where the superintendent and elementary school principal were present and where she was informed that other students had accused her of drug possession. ${ }^{8}$ Subsequently, Jane was escorted to the nurse's office for a strip search, in which she was forced to remove all of her clothing and stand naked while the elementary school principal and nurse searched them. ${ }^{9}$ No drugs or contraband were found during this search. ${ }^{10}$ Subsequently, the nurse, in the presence of the elementary school principal, conducted a visual rectal and vaginal search for drugs, during which the nurse laughed and stated, "[T]his is

${ }^{2}$ Alex Sundby, Lawsuit: Mo. Girl Expelled for Making Rape Claim, CBS NEws (Aug. 17, 2011), http://www.cbsnews.com/news/lawsuit-mo-girl-expelled-for-making-rape-claim [https://perma.cc/F3LS-3KTD] (discussing the lawsuit's claims).

${ }^{3}$ Id.

${ }^{4}$ Alyssa Newcomb, Special Needs Girl Sues School for Forcing Her To Apologize to Her Rapist, ABC NEwS (Aug. 17, 2011), http://abcnews.go.com/US/special-student-suesmissouri-school-district-rapes/story?id=14325659 [https://perma.cc/FN8T-ST9D].

${ }^{5} I d$. (discussing the lawsuit's allegations).

${ }^{6}$ CNN Wire Staff, Lawsuit Alleges Missouri School Expelled Girl for Making Rape Claim, CNN (Aug. 18, 2011), http://www.cnn.com/2011/CRIME/08/18/missouri.school.rape. claim/ [https://perma.cc/EP4V-5QWX].

${ }^{7}$ See Ugo Uche, School Forces Little Girl To Apologize to the Boy Who Raped Her, PSYCHOL. TODAY (Aug. 22, 2011), https:/www.psychologytoday.com/blog/promotingempathy-your-teen/201108/school-forces-little-girl-apologize-the-boy-who-raped-her [https://perma.cc/2DMB-5A5M] (discussing the forced apology's compounding effect in harming the student).

${ }^{8}$ Complaint at 3-4, Doe v. Finster, No. 7:16-cv-1467 (FJS/ATB) (N.D.N.Y. Dec. 8, 2016). The allegations of this complaint are provided throughout this text paragraph.

${ }^{9}$ Id. at 4-5.

${ }^{10}$ Id. at 5. 
a first ...."11 Again, no contraband was found. ${ }^{12}$ After one hour and twenty minutes of this "shameful treatment and embarrassment," Jane's clothing was returned and she was permitted to dress. ${ }^{13}$ Jane's request to call her father was summarily denied. ${ }^{14}$ According to Jane, the strip search was "frightening, degrading, and de-humanizing," 15 and it resulted in severe mental anguish and "permanent loss of natural psychological development." 16

Across the country, K-12 schools, teachers, and administrators are inflicting shaming punishments upon students for noncompliance or suspicion of noncompliance with school or classroom rules. ${ }^{17}$ These in-school shaming sanctions are designed to punish behavior by making an example of the targeted student in front of his or her peers, teachers, administrators, or the broader school community. ${ }^{18}$ Rather than removing the child from school grounds or imposing physical pain upon the child, these shaming punishments shine a bright spotlight upon the offending student and his or her conduct ${ }^{19}$ while keeping the student within the schoolhouse gate. School shaming punishments fall into a myriad of categories, which include publicly displayed personal behavior systems, ${ }^{20}$ forced isolation, ${ }^{21}$ compelled apologies, ${ }^{22}$ invasive searches, ${ }^{23}$ and scarlet letter punishments for dress code violations. ${ }^{24}$ Although the shaming punishments that are being implemented in American schools are

11 Id. at 6-7.

${ }^{12} \mathrm{Id}$.

13 Id. at 7.

${ }^{14}$ See Complaint, supra note 8 , at 7.

$15 \mathrm{Id}$. at 8.

${ }^{16} \mathrm{Id}$.

${ }^{17}$ See, e.g., Ann Monroe, Shame Solutions: How Shame Impacts School-Aged Children and What Teachers Can Do To Help, 73 EDUC. F. 58, 66 (2009) (stating schools "all too often ... perpetuate the cycle of shame").

18 See Jessica A. Clarke, Against Immutability, 125 YAle L.J. 2, 21-22 (2015) ("Shaming penalties have historically been employed to reaffirm class relationships and reinforce the shamed person's subordinate status.").

${ }^{19} \mathrm{Cf}$. Wayne A. Logan, Federal Habeas in the Information Age, 85 MINN. L. REV. 147, 176 (2000) (discussing how shaming sanctions focus concentrated negative community attention on the alleged rule violator).

20 June Price TANgney \& Ronda L. Dearing, Shame AND Gullt 188 (2002) (classifying writing schoolchildren's names on the classroom chalkboard as a shaming punishment).

${ }^{21} \mathrm{Id}$. (classifying the placement of students in a corner or a separate area from their peers as a shaming punishment).

${ }^{22}$ Brent T. White, Say You're Sorry: Court-Ordered Apologies as a Civil Rights Remedy, 91 CORNELL L. REV. 1261, 1286-87 (2006) (characterizing compelled apologies as shaming sanctions).

${ }^{23}$ See Kathryn M. Stanchi, The Power of Priming in Legal Advocacy: Using the Science of First Impressions To Persuade the Reader, 89 OR. L. REV. 305, 327 (2010) (describing a student's deep-seated humiliation when forced to undergo a strip search).

${ }^{24}$ Meredith Johnson Harbach, Sexualization, Sex Discrimination, and Public School Dress Codes, 50 U. RICH. L. REV. 1039, 1043-44 (2016) (characterizing dress code violation enforcements as shaming punishments). 
diverse, their common denominator is the goal to attach stigma to the student who has allegedly violated the rules by engaging in state-deemed shameful behavior. ${ }^{25}$

While there has been a significant amount of legal scholarship dedicated to the clearly detrimental effects of exclusionary punishment ${ }^{26}$ and corporal punishment, ${ }^{27}$ there has been almost no critical analysis of shaming punishments in schools. The aim of this Article is to fill this void by examining these punishments' lack of efficacy, outlining their substantial harm, and advocating for their cessation through a constitutional lens. Specifically, Part II of this Article will provide definitional context to shaming punishments and their inherent stigma by focusing on the work of sociologist Erving Goffman and criminologist John Braithwaite. Thereafter, Part II will demonstrate that, like exclusionary and corporal punishments, shaming punishments fail to meet any type of efficacy metric, based on their nondeterrent, nonrehabilitative, and nonreformative nature. Part II will then explore the damaging effects of shaming punishments in schools, on both the disciplined students and the greater school community, via an extended comparison between exclusionary punishments, corporal punishments, and in-school shaming punishments.

Part III presents the normative rejection of shaming punishments based on how they can result in violations of students' First and Fourth Amendment rights, which might give rise to liability in individual and derivative 42 U.S.C. $\S 1983$ lawsuits. This Part will use paradigmatic case examples to illustrate how the specific school shaming punishments of compelled apologies and strip searches can exceed the constitutional limits of the considerable deference that has been extended to schools and their employees by the courts in disciplinary matters. Under a purely utilitarian perspective, schools and their employees should no longer use shaming as a disciplinary measure in order to avoid the

25 E.g., Kaaryn Gustafson, Degradation Ceremonies and the Criminalization of LowIncome Women, 3 U.C. IRVINE L. REV. 297, 301 (2013) (defining shaming degradation ceremonies as "communicative work "whereby the public identity of an actor is transformed into something looked on as lower in the local scheme of social types" (quoting Harold Garfinkel, Conditions of Successful Degradation Ceremonies, 61 AM. J. Soc. 420, 420 (1956))).

${ }^{26}$ See, e.g., Derek W. Black, The Constitutional Limit of Zero Tolerance in Schools, 99 MINN. L. REV. 823, 833 (2015) (describing suspension and expulsion "as de facto educational death penalties [rather] than ... corrective or management tools"); S. David Mitchell, Zero Tolerance Policies: Criminalizing Childhood and Disenfranchising the Next Generation of Citizens, 92 WASH. U. L. REV. 271, 291 (2014) (discussing the school-toprison pipeline as one harm of exclusionary school punishments).

${ }^{27}$ E.g., Susan H. Bitensky, The Poverty of Precedent for School Corporal Punishment's Constitutionality Under the Eighth Amendment, 77 U. CIN. L. REv. 1327, 1353 (2009) (arguing school corporal punishments violate the Eighth Amendment); Deana Pollard Sacks, State Actors Beating Children: A Call for Judicial Relief, 42 U.C. DAVIS L. REV. 1165, 1169 (2009) (describing corporal punishment's impact on children as "profound, dangerous, and enduring"). 
monetary and injunctive liability that can result from these lawsuits. ${ }^{28}$ More importantly, ${ }^{29}$ though, schools and their employees should end their use of shaming as a method of punishment to avoid violating the constitutional rights of their students. ${ }^{30}$

Finally, Part IV will conclude by advocating for the end of school shaming punishments and by previewing more beneficial consequential alternatives to address student conduct that can restore respect, rather than exacerbate stigma, among all school community constituencies. By replacing shaming with consequential methods for Positive Behavioral Interventions and Supports, ${ }^{31}$ schools can fulfill their obligation to provide an appropriate educational environment, which will effectively serve to awaken children to cultural values and to prepare them to be active, well-adjusted adults in society. ${ }^{32} \mathrm{~A}$ liberal democracy should require no less. 33

\section{The INEFFICACY AND HARM OF SCHOOL SHAMING PUNISHMENTS}

In Brown v. Board of Education, the Supreme Court recognized that "education is perhaps the most important function of state and local governments," deeming it "the very foundation of good citizenship." 34 Education prepares students to be self-reliant, self-sufficient, active participants

28 See Davis ex rel. LaShonda D. v. Monroe Cty. Bd. of Educ., 526 U.S. 629, 649 (1999) (acknowledging "school administrators shoulder substantial burdens as a result of legal constraints on their disciplinary authority" and discussing the importance of clear standards for disciplinary authority to avoid "potential liability arising from certain forms of disciplinary action").

${ }^{29}$ See, e.g., Emmalena K. Quesada, Note, Innocent Kiss or Potential Legal Nightmare: Peer Sexual Harassment and the Standard for School Liability Under Title LX, 83 CORNELL L. REV. 1014, 1067 (1998) (discussing how avoidance of liability is not the best reason to eliminate rights-violative conduct in schools).

${ }^{30}$ See Vernonia Sch. Dist. 47J v. Acton ex rel. Acton, 515 U.S. 646, 655-56 (1995) ("[C]hildren assuredly do not 'shed their constitutional rights ... at the schoolhouse gate...." (quoting Tinker v. Des Moines Indep. Cmty. Sch. Dist., 393 U.S. 503, 506 (1969))); W. Va. State Bd. of Educ. v. Barnette, 319 U.S. 624, 638 (1943) (providing state school entities and actors are not "beyond reach of the Constitution").

${ }^{31}$ Neelum Arya, Family-Driven Justice, 56 ARIZ. L. REV. 623, 669 (2014) (arguing PBIS can provide "positive school environments and cultures to improve the behavior of students"). See generally Homepage, Positive BEHAVIORAL INTERVENTIONS \& SUPPORTS (PBIS), http://www.pbis.org [https://perma.cc/9KCE-BE3L] (stating the "purpose of PBIS is to improve the effectiveness, efficiency[,] and equity of schools" and to improve "social, emotional[,] and academic outcomes for all students").

${ }^{32}$ Brown v. Bd. of Educ., 347 U.S. 483, 493 (1954) (stating education is a principal instrument in achieving these goals).

${ }^{33}$ See Barnette, 319 U.S. at 637 ("That [boards of education] are educating the young for citizenship is reason for scrupulous protection of Constitutional freedoms of the individual, if we are not to strangle the free mind at its source and teach youth to discount important principles of our government as mere platitudes.").

${ }^{34}$ Brown, 347 U.S. at 493; see also Wisconsin v. Yoder, 406 U.S. 205, 213 (1972) ("[P]ublic schools rank $[$ at the very apex of the function of a State."). 
in society. ${ }^{35}$ Despite this nexus between public education and legal socialization, ${ }^{36}$ "public school entrance is often reported as the [first] occasion of stigma learning, the experience sometimes coming very precipitously on the first day of school, with taunts, teasing, ostracism, and fights." 37 Unfortunately, schools, administrators, and teachers, as state actors, are often the impetus for this stigma learning for schoolchildren through the imposition of shaming punishments. 38

These punishments are ineffective methods of school discipline, like exclusionary and corporal punishments, as they are nondeterrent, nonrehabilitative, and nonreformative. ${ }^{39}$ In addition to being ineffective, shaming punishments are deleterious school disciplinary methods that inflict substantial and unacceptable harm on both the punished students and the greater school community, similar to the damages that result from exclusionary and corporal punishments. ${ }^{40}$ Consequently, in alignment with the call for the end of exclusionary and corporal punishments as methods of school discipline, ${ }^{41}$ it is time for a cessation of the infliction of in-school stigmatizing punishments upon schoolchildren.

\section{A. School Shaming Punishments and Stigma-A Definitional Framework}

Many public schools are now implementing in-school shaming punishments as an alternative or corollary sanction to exclusionary and corporal

35 Yoder, 406 U.S. at 221 (describing how schools prepare students to participate and engage in society).

36 Josie Foehrenbach Brown, Developmental Due Process: Waging A Constitutional Campaign To Align School Discipline with Developmental Knowledge, 82 TEMP. L. REV. 929, 930 (2009) ("Public schools are critical sites in children's legal socialization. Serving close to ninety percent of our country's elementary and secondary students, public schools imprint better and worse versions of the Constitution-in-practice on children's nascent legal consciousness.").

37 ERving Goffman, Stigma 33 (1963).

${ }^{38}$ See Maurice R. Dyson, Promise Zones, Poverty, and the Future of Public Schools: Confronting the Challenges of Socioeconomic Integration \& School Culture in High-Poverty Schools, 2014 MICH. ST. L. REV. 711, 732-33 (2014) (describing a school's practice of publicly singling out and isolating elementary school students with unfinished homework in the cafeteria during lunch as a shaming punishment that generates stigma).

${ }^{39}$ See infra Part II.B.1.

${ }^{40}$ See infra Part II.B.2-3.

41 E.g., Derek W. Black, Reforming School Discipline, 111 NW. U. L. REV. 1, 73-74 (2016) (analyzing the harm of exclusionary discipline and calling for its reform as "a necessary intervention to ensure adequate and equal educational opportunities"); Letter from John B. King, Jr., U.S. Sec'y of Educ., to Governors and Chief State School Officers 1 (Nov. 22, 2016), https:/www2.ed.gov/policy/gen/guid/school-discipline/files/corporal-punishment-dcl11-22-2016.pdf [https://perma.cc/Q8CW-V6B5] (advocating for the elimination of harmful school corporal punishment). 
punishments. ${ }^{42}$ School shaming is a disciplinary method of publicizing a student's alleged wrongful behavior in the school community, "where such behavior is perceived to have violated a social norm." 43 School shaming punishments are designed to stigmatize a noncompliant student. ${ }^{44}$ Erving Goffman, the most influential symbolic interactionist sociologist of the twentieth century, ${ }^{45}$ deemed stigma to be "an undesired differentness," 46 which dehumanizes the person targeted by its infliction. ${ }^{47}$ This dehumanization and subordination occur when schools shame students. ${ }^{48}$ The stigma that accompanies shaming punishments has a magnifying and multiplying effect, as it results in the imputation of an extensive array of imperfections based only on the original one. ${ }^{49}$ Thus, these punishments demarcate the student as "the other," as compared to the "normal" school community. ${ }^{50}$

\section{B. Shaming Punishments-An Equally Ineffective and Harmful School Disciplinary Alternative}

There is scant reliable data on the imposition of noncorporal shaming punishments in schools. ${ }^{51}$ This dovetails with a broader paucity of

${ }^{42}$ See supra Part I (detailing a variety of school shaming punishments).

${ }^{43}$ Leah Chan Grinvald, Shaming Trademark Bullies, 2011 WIS. L. REV. 625, 665 (2011) (citing ERIC A. POSNER, LAW AND SOCIAL NORMS 76 (2000)).

${ }^{44}$ See Note, Shame, Stigma, and Crime: Evaluating the Efficacy of Shaming Sanctions in Criminal Law, 116 HARV. L. REV. 2186, 2188 (2003) ("[S]haming penalties usually stigmatize the offender to an extent that would not occur in their absence ... [and] attempt to mark the offender publicly as a deviant.").

${ }^{45}$ Robert C. Post, The Social Foundations of Defamation Law: Reputation and the Constitution, 74 CALIF. L. REV. 691, 709 (1986) (describing the primacy of Goffman's sociological theory).

46 GOFFMAN, supra note 37 , at 5.

${ }^{47}$ Id. ("By definition, of course, we believe the person with a stigma is not quite human.").

48 See Clarke, supra note 18, at 22 ("Stigmatizing practices go beyond expressing disapproval of a particular act or behavior to impose a 'spoiled identity' on their targets." (citing GOFFMAN, supra note 37, at 2-3)).

${ }^{49}$ GOFFMAN, supra note 37 , at 5 (identifying the compounding nature of stigmatizing shaming).

${ }^{50}$ Kenneth L. Karst, Myths of Identity: Individual and Group Portraits of Race and Sexual Orientation, 43 UCLA L. REV. 263, 286 (1995) (discussing this shaming demarcation).

${ }^{51}$ E.g., Lewis R. Katz \& Carl J. Mazzone, Safford Unified School District No. 1 v. Redding and the Future of School Strip Searches, 60 CASE W. RES. L. REV. 363, 363-64 (2010) (discussing the underreporting of school strip searches because most states and school boards do not have requirements for their data collection, resulting in most only becoming known "when a student has the courage to tell a parent"); School Climate and Discipline, U.S. DEP'T EDUC., https://www2.ed.gov/policy/gen/guid/school-discipline/index.html\#featured [https://perma.cc/NG9N-UJSV] (last updated Jan. 4, 2017) (featuring no mention of shaming punishments in the "tools, data[,] and resources" available on the website for "[a]dministrators, educators, students, parents[,] and community members"). 
comprehensive data in the area of school discipline, ${ }^{52}$ as the decentralization of education makes it an exceedingly difficult area to monitor as an empirical matter. ${ }^{53}$ Existing federal and state efforts to track discipline have revolved around exclusionary punishments, ${ }^{54}$ law enforcement referrals, ${ }^{55}$ or corporal punishments. ${ }^{56}$ There are not analogous reporting mechanisms for shaming punishments. ${ }^{57}$ Because shaming punishments are not monitored systematically and comprehensively, this lack of transparency in their use fails to establish their efficacy and carries with it inherent harm for individual students and larger school communities. Without accurate public reporting of the use of school shaming punishments and their impact on schoolchildren, there is little accountability regarding their imposition and little internal impetus to advocate for their cessation. ${ }^{58}$

Given the lack of transparency regarding shaming punishments and the relative clarity of the lack of deterrent value and substantial harm of exclusionary and corporal punishments, ${ }^{59}$ it appears that schools and their employees may utilize in-school, noncorporal shaming punishments under a false perception that they are a more beneficial and less detrimental alternative to other punishments. However, this rationale is a false and faulty one. As a

${ }^{52}$ Logan J. Gowdey, Note, Disabling Discipline: Locating a Right to Representation of Students with Disabilities in the ADA, 115 COLUM. L. REV. 2265, 2277 n.58 (2015) (discussing the lack of a systematic collection of school discipline data).

${ }^{53}$ Note, supra note 44, at 2189 (noting "the lack of any systematic structure for imposing such [shaming] penalties has made comprehensive data collection on the issue virtually impossible").

54 See Daniel J. Losen, Discipline Policies, Successful Schools, Racial Justice, and the Law, 51 FAM. CT. REV. 388, 389 (2013) (discussing the U.S. Department of Education's Office for Civil Rights' collection of data on school exclusionary punishments).

${ }^{55}$ Catherine Y. Kim, Policing School Discipline, 77 BROOK. L. REV. 861, 888-89 (2012) (outlining law enforcement referrals in school disciplinary data).

${ }^{56}$ E.g., School Climate and Discipline, supra note 51 (including multiple federal and state statistical and advocacy resources related to exclusionary and corporal punishments).

${ }^{57}$ See, e.g., Discipline Report, ED.GOV, http:/ocrdata.ed.gov/DataAnalysisTools/DataSet Builder?Report $=6$ (click on "Search for Schools Based on Data Element Criteria" then click on "Discpline") (on file with Ohio State Law Journal) (defining discipline criteria only as "students who received at least one out-of-school suspension[,] students who received an expulsion[,] and students referred to law enforcement").

${ }^{58}$ Daniel J. Losen, Conclusion, in Closing THE SChOOL Discipline GaP 241, 248 (Daniel J. Losen ed., 2015) ("[U]ntil discipline data are incorporated into the broader accountability rubrics used by states to evaluate schools and districts, it is unlikely we will witness comprehensive and lasting improvements in the area of school discipline."); Jason P. Nance, Dismantling the School-to-Prison Pipeline: Tools for Change, 48 ARIZ. ST. L.J. 313,362 (2016) (arguing required school discipline data collection is a necessary measure for accountability and effecting change).

${ }^{59}$ Black, supra note 41 , at 4 (discussing the nondeterrence and substantial harm of exclusionary school discipline); Brown, supra note 36 , at 955 (outlining research that finds "the absence of a legitimate pedagogical purpose for the use of physical punishment and the probability that such disciplinary methods are far more likely to harm both individual students and the learning enterprise overall"). 
preliminary matter, exclusionary punishments and corporal punishments are shaming punishments, ${ }^{60}$ as they fit within their definitional framework. ${ }^{61}$ Further, the actuality is that shaming punishments are an equally ineffective and harmful disciplinary alternative.

As such, the corollaries between these types of school sanctions are an important jumping-off point in the examination of the parallel lack of efficacy and the significant damage they inflict. The first part of this analysis, then, must include the ideology of effective discipline, which is "an institutionalized response to the violation of some official rule or regulation proscribing certain conduct and is imposed for the purpose of rehabilitating the offender, deterring the offender and others ... from committing the violation in the future, and inflicting some measure of social retribution for the harm ... done." ${ }^{\prime 62}$ Exclusionary, corporal, and in-school shaming punishments satisfy only that last criteria of this foundational definition, because they are all examples of retributive, deleterious punishments for students. ${ }^{63}$ Like exclusionary and corporal punishments, shaming punishments are equally ineffective; they are nondeterrent, nonrehabilitative, and nonreformative. ${ }^{64}$ Like exclusionary and corporal punishments, shaming punishments inflict substantial and lasting harm on individual students ${ }^{65}$ and generate equivalent negative societal collateral consequences. ${ }^{66}$ Therefore, just as exclusionary and corporal punishments should be abandoned as methods to sanction schoolchildren, shaming punishments likewise should be abandoned.

\section{School Shaming Punishments Are Inefficacious}

School shaming punishments do not satisfy a standard of efficacy, as they fail to meet the criteria of deterrence, rehabilitation, and reformation. These punishments fall squarely within Professor Braithwaite's definition in Crime, Shame and Reintegration of stigmatic disintegrative shaming, which involves

${ }^{60}$ See James Q. Whitman, Essay, What Is Wrong with Inflicting Shame Sanctions?, 107 YALE L.J. 1055, 1060 (1998) ("[E]very punishment can involve some element of shaming.").

${ }^{61}$ See Nora V. Demleitner, Is There a Future for Leniency in the U.S. Criminal Justice System?, 103 MiCH. L. REV. 1231, 1241 (2005) (reviewing JAMES Q. WhITMAN, HARSH JUSTICE (2003)) (noting shaming is exclusionary); Dan M. Kahan, What Do Alternative Sanctions Mean?, 63 U. CHI. L. REV. 591, 611 (1996) (connecting shaming and corporal punishment); Judith A.M. Scully, Examining and Dismantling the School-to-Prison Pipeline: Strategies for a Better Future, 68 ARK. L. REV. 959, 987 (2016) (arguing exclusionary punishments "increase student shame, alienation, and feelings of rejection" (quoting LaURA FaER \& SARAH OMOJOLA, FIX SCHOOl Discipline: How We CAN FIX SCHOOL DISCIPLINE TOOLKIT 5 (2012), http://www.smcoe.org/assets/files/about-smcoe/FixSchool-Discipline-Toolkit-for-Educators.pdf [https://perma.cc/5Z4F-VXLK])).

${ }^{62}$ Ingraham v. Wright, 430 U.S. 651, 685-86 (1977) (White, J., dissenting).

${ }^{63}$ See infra Part II.B.1.

${ }^{64}$ See infra Part II.B.1.

${ }^{65}$ See infra Part II.B.2.

${ }^{66}$ See infra Part II.B.3. 
an individual, intense condemnation of the punished and which creates community division through the creation of a class of outcasts. ${ }^{67}$ With disintegrative school shaming punishments, like exclusionary punishments and corporal punishments, ${ }^{68}$ positive social norms are neither expressly taught nor internalized, which destroys the efficacy of a positive disciplinary measure in schools. ${ }^{69}$ When positive social norms are neither expressly taught nor internalized, the punished student has no guidance on how to ascribe to those norms. ${ }^{70}$ Consequently, shaming punishments are inherently ineffective.

Like exclusionary ${ }^{71}$ and corporal punishments, ${ }^{72}$ disintegrative shaming punishments are ineffective because they are unlikely to act as specific deterrents for future rules-violative behavior by the punished student. ${ }^{73}$ These sanctions will not achieve individual deterrence when the punished student disagrees with the validity of the shaming imposed for the targeted behavior, ${ }^{74}$

67 John BRaITHWAITE, CRIME, SHAME AND REINTEGRATION 55 (1989). Throughout this Article, criminal punishment theory will be used to support the cessation of shaming punishments in schools. These connections are relevant, given the parallels between state control in the criminal justice system and America's schools. See, e.g., Aaron H. Caplan, Freedom of Speech in School and Prison, 85 WASH. L. REV. 71, 73 (2010) (discussing the frequency of court opinions that analogize constitutional rights in schools to constitutional rights in prisons).

${ }^{68}$ See, e.g., Murray A. Straus \& Carrie L. Yodanis, Corporal Punishment by Parents: Implications for Primary Prevention of Assaults on Spouses and Children, 2 U. CHI. L. SCH. ROUNDTABLE 35, 38 (1995) ("[E]xperience with corporal punishment lays the groundwork for the norms legitimizing violence of all types ....").

${ }^{69}$ See Sandeep Gopalan, Changing Social Norms and CEO Pay: The Role of Norms Entrepreneurs, 39 RUTGERS L.J. 1, 18 (2007) (arguing a shaming sanction is only effective when the corresponding norm is discovered and internalized).

${ }^{70}$ See Andrew Horwitz, Coercion, Pop-Psychology, and Judicial Moralizing: Some Proposals for Curbing Judicial Abuse of Probation Conditions, 57 WASH. \& LEE L. REV. 75, 147 (2000) (arguing shaming punishments minimize or even eliminate the offender's incentive to conform to societal norms).

${ }^{71}$ Black, supra note 26, at 833 (discussing how school exclusionary punishment "becomes a predictor, rather than a deterrent, of later ... discipline problems").

${ }^{72}$ Leonard P. Edwards, Corporal Punishment and the Legal System, 36 SANTA CLARA L. REV. 983, 1020 (1996) (arguing corporal punishment is not an effective way to control children's behavior); King, supra note 41 , at 2 (discussing the nondeterrence of school corporal punishments).

73 BRAITHWAITE, supra note 67, at 59-60 (concluding disintegrative shaming does not have a specific deterrent effect); see also Clarke, supra note 18, at 21 ("Whether shaming is generally effective in shaping behavior, as an empirical matter, is disputed and depends on context."); Adam M. Gershowitz, Prosecutorial Shaming: Naming Attorneys To Reduce Prosecutorial Misconduct, 42 U.C. DAVIS L. REV. 1059, 1104 n.247 (2009) (noting the conjectural nature of shaming's deterrent effects).

${ }^{74}$ Richard A. Posner \& Eric B. Rasmusen, Creating and Enforcing Norms, with Special Reference to Sanctions, 19 INT'L REV. L. \& ECON. 369, 374 (1999) (arguing that sanctions will fail if the punished individual "shrugs off the criticisms as a product of ignorance, malice, or envy"). 
and they do not guarantee contrition. ${ }^{75}$ Further, shaming punishments can have the inverse effect of intended deterrence; ${ }^{76}$ the imposition of shame can lead to more state-deemed shameful behavior. ${ }^{77}$ Given the continuing cognitive development throughout childhood and adolescence, ${ }^{78}$ school shaming punishments do not serve as effective individual deterrents. ${ }^{79}$

Like exclusionary punishments ${ }^{80}$ and corporal punishments, ${ }^{81}$ school shaming punishments also do not necessarily have a general deterrent effect for other schoolchildren. ${ }^{82}$ Professor Braithwaite argued that disintegrative shaming sanctions do not act as deterrents for the greater community, because "public exhibitions of state acts of brutality ... [do] as much to legitimate brutality as [they do] to delegitimate" the rules-violative behavior ${ }^{83}$ Any deterrent-effects justification for school shaming is weakened by the fact that the school cannot accurately gauge the community reaction to such shaming. ${ }^{84}$ Shaming penalties, which inherently rely on the creation of emotion in the community to deter future behavior within the student body, are problematic in

75 Martha Minow, Essay, Forgiveness, Law, and Justice, 103 CALIF. L. REV. 1615, 1620 (2015) ("Law may force statements of apology and forgiveness, but it cannot compel the feelings they are meant to express.").

${ }^{76}$ See Peter H. Huang \& Christopher J. Anderson, A Psychology of Emotional Legal Decision Making: Revulsion and Saving Face in Legal Theory and Practice, 90 MINN. L. REV. 1045, 1064 (2006) (reviewing MarTHA C. NuSSBAUM, HIDING From HuMANITY: DISGUST, SHAME, AND THE LAW (2004)) (highlighting the immunizing nature of shaming on its intended targets).

${ }^{77}$ Horwitz, supra note 70, at 147-48 ("[T] he mere labeling of an offender as deviant can actually lead to further deviant behavior.").

${ }^{78}$ Alicia N. Harden, Rethinking the Shame: The Intersection of Shaming Punishments and American Juvenile Justice, 16 U.C. DAVIS J. JUV. L. \& POL'Y 93, 114-15 (2012) (arguing that juvenile shaming punishments fail as general and specific deterrents because adolescent brain development indicates children cannot reason like adults).

${ }^{79}$ Amy E. Halbrook, Juvenile Pariahs, 65 HaSTings L.J. 1, 51 (2013) ("Lack of maturity undermines the goal of deterrence ....").

${ }^{80}$ Brown, supra note 36 , at 963 (deeming exclusionary punishments as "counterproductive, igniting student hostility toward school officials and eroding the sense of school connectedness critical to a student's academic success and behavioral improvement").

${ }^{81}$ Deana Pollard, Banning Child Corporal Punishment, 77 TuL. L. REV. 575, 578 (2003) (stating corporal punishment is an ineffective teaching method).

82 See John A. Bozza, "The Devil Made Me Do It": Legal Implications of the New Treatment Imperative, 12 S. CAL. INTERDISC. L.J. 55, 81-82 (2002) (discussing the theoretical nature of deterrence theory with shaming punishments); Stephen P. Garvey, Can Shaming Punishments Educate?, 65 U. CHI. L. REv. 733, 753-54 (1998) (finding the lack of empirical inquiry regarding shaming punishments makes deterrence claims "highly speculative").

${ }^{83}$ BRAITHWAITE, supra note 67, at 59.

${ }^{84}$ Michael L. Perlin \& Naomi M. Weinstein, "Friend to the Martyr, a Friend to the Woman of Shame": Thinking About the Law, Shame, and Humiliation, 24 S. CAL. REV. L. \& SOC. JUST. 1, 24 (2014) (discussing the weakened nature of a deterrence justification based on the government's inability to assess public reaction to shaming). 
that human emotion is an unpredictable variable for deterrence. ${ }^{85}$ Also, the commonplace use of school shaming punishments significantly mitigates their deterrent value. 86 "When the basis for students' trust in school officials has been eroded through personal mistreatment or observing the mistreatment of others, little hope for rule compliance exists as their bond with authority has been compromised." 87 Therefore, shaming punishments are inefficacious as they have neither a specific nor a general deterrent effect.

Finally, school shaming punishments fail to meet a standard of efficacy as they run counter to rehabilitation and reformation, ${ }^{88}$ like exclusionary and corporal punishments. ${ }^{89}$ Rehabilitative dispositions are geared toward the alleviation of harmful conditions to improve punished students; they are not inflicted to make students suffer for their conduct. ${ }^{90}$ Reformative discipline aims to transform punished students through appeals to their morality and conscience. ${ }^{91}$ Although schoolchildren who violate school rules and policies are uniquely situated to benefit from rehabilitative and reformative discipline, ${ }^{92}$ school shaming punishments are neither rehabilitative nor reformative. ${ }^{93}$ When schools implement harsh and punitive discipline, like shaming punishments, undesirable conditions are not alleviated, as is the goal with rehabilitative

85 Jeremy A. Blumenthal, Law and the Emotions: The Problems of Affective Forecasting, 80 IND. L.J. 155, 233-34 (2005) (noting the deterrent effect of shaming penalties cannot be predicted due to unpredictable human emotion).

${ }^{86}$ Alon Harel, Why Only the State May Inflict Criminal Sanctions: The Argument from Moral Burdens, 28 CARDOZO L. REV. 2629, 2636 (2007) (discussing the erosion of a deterrent effect when shaming punishments become a standard of course).

${ }^{87}$ Brown, supra note 36, at 994.

${ }^{88}$ See generally Meghan J. Ryan, Death and Rehabilitation, 46 U.C. DAVIS L. REV. 1231,1262 (2013) (discussing the differences between rehabilitation and reformation).

89 See Joshua Kleinfeld, Two Cultures of Punishment, 68 STAN. L. REV. 933, 965 (2016) (discussing how exclusionary punishments "deprive the offender of recognition in the social world" rather than rehabilitating or reforming them); Edwin J. Lukas, Book Review, 58 HARv. L. Rev. 630, 630 (1945) (reviewing Thorsten SEllin, PIONEERING IN PENOLOGY (1944)) (arguing child corporal punishment is antithetical to modern culture, which values reformation in schools).

${ }^{90}$ Martin R. Gardner, "Decision Rules" and Kids: Clarifying the Vagueness Problems with Status Offense Statutes and School Disciplinary Rules, 89 NEB. L. REV. 1, 21 (2010) (defining the nature of rehabilitative punishments).

91 Cf. Stephanos Bibas, Bringing Moral Values into a Flawed Plea-Bargaining System, 88 CORNELL L. REV. 1425, 1430 (2003) (discussing reformation in punishment theory).

${ }^{92}$ Recent Case, Criminal Law Sex Offender Registration-Ninth Circuit Holds that Retroactive Application of SORNA to Juvenile Violates Ex Post Facto Clause - United States v. Juvenile Male, 581 F.3d 977 (9th Cir. 2009), 123 HARv. L. REV. 1524, 1530 (2010) (claiming lower rates of recidivism demonstrate juvenile offenders are particularly responsive to rehabilitation).

${ }^{93}$ See Courtney Guyton Persons, Note, Sex in the Sunlight: The Effectiveness, Efficiency, Constitutionality, and Advisability of Publishing Names and Pictures of Prostitutes' Patrons, 49 VAND. L. REV. 1525, 1547 (1996) (arguing shaming sanctions are not effective mechanisms of rehabilitation). 
treatment; instead, undesirable conditions are aggravated. ${ }^{94}$ Further, these punishments, by perpetuating the negative indignation of shame, lack the potentiality of individual reformation, ${ }^{95}$ analogous to the result of the immoral infliction of exclusionary and corporal punishments in schools.

In conclusion, like exclusionary and corporal punishments, shaming punishments are inefficacious disciplinary methods in an educational environment. They are all examples of purely retributive punishments, ${ }^{96}$ which solely justify the suffering of the penalized student on the notion that the student deserves the suffering, rather than any beneficial consequences that might be achieved by the discipline. ${ }^{97}$ In fact, shaming punishments fall squarely within the Kantian definition of retributivism, as they implement the idea that the student "must be punished, regardless of the consequences." 98 The disciplinary ideology that a student who allegedly violates school rules deserves the shaming punishment, ${ }^{99}$ and its attendant moral condemnation and assignation of stigma, with little hope of ameliorative consequences, ${ }^{100}$ has no place within the schoolhouse gate. Further, shaming punishments lack efficacy in terms of the instillation or communication of positive social norms. ${ }^{101}$ School shaming punishments are therefore nondeterrent, nonrehabilitative, and

${ }^{94}$ Brown, supra note 36 , at 963 ("[S]chools exhibiting a harsh and punitive disciplinary approach diminish the likelihood that students will view the school as supportive.").

${ }^{95}$ See Chad Flanders, The Supreme Court and the Rehabilitative Ideal, 49 GA. L. REV. 383,429 (2015) (postulating that all punishments should be constrained by whether they provide the possibility of moral reform).

${ }^{96}$ See Xiyin Tang, Shame: A Different Criminal Law Proposal for Bullies, 61 CLEV. ST. L. REV. 649, 657 (2013) (discussing shaming's retributive nature); Developments in the Law - Corporate Crime: Regulating Corporate Behavior Through Criminal Sanctions, 92 HARV. L. REV. 1227, 1234 n.10 (1979) (arguing the imposition of sanctions for "purely retributive reasons ... cause[s] needless suffering with no beneficial consequences").

${ }^{97}$ Russell L. Christopher, Deterring Retributivism: The Injustice of "Just" Punishment, 96 Nw. U. L. REV. 843, 847-48 (2002) (defining retributivism as a concept that "justifies punishment, or the suffering by the punished, not on any actual good consequences that might be attained, but solely because the punished deserve it").

98 Dan Markel, Are Shaming Punishments Beautifully Retributive? Retributivism and the Implications for the Alternative Sanctions Debate, 54 VAND. L. REV. 2157, 2159 (2001).

${ }^{99}$ See Kahan, supra note 61, at 601-02 ("A retributivist punishes because, and only because, the offender deserves it." (quoting Michael S. Moore, The Moral Worth of Retribution, in RESPONSIBLITY, CHARACTER, AND THE EMOTIONS 179, 179 (Ferdinand Schoeman ed., 1987))).

${ }^{100}$ See Gabriella Blum, The Crime and Punishment of States, 38 YALE J. INT'L L. 57, 59 (2013) (defining the goals of punitive action as "to assign blame and engage in retribution").

101 See John Bronsteen et al., Retribution and the Experience of Punishment, 98 CALIF. L. REV. 1463, 1496 (2010) ("To the extent that the goal of punishment is to communicate condemnation to offenders, communicating the appropriate message depends upon imposing appropriate, proportional levels of negative experience."). 
nonreformative. ${ }^{102}$ Consequently, these counterproductive punishments should be eliminated from school use under an efficacy or utilitarian theory. ${ }^{103}$

\section{Shaming Punishments Inflict Substantial and Lasting Harm on Individual Students}

Like exclusionary 104 and corporal punishments, 105 school shaming punishments inflict substantial and lasting harm on the students who have been deemed rule violators in the school community. 106 The stigma that results from shaming punishments creates isolation, exacerbates anger, and often instigates magnified antisocial behaviors in the penalized children. ${ }^{107}$ These negative outcomes can impact the students' continued success in the school community and in broader society. ${ }^{108}$ The detrimental outcomes that result from shaming punishments do not stop in childhood; they can extend to have permanent destructive effects into adulthood. ${ }^{109}$ Because these shaming punishments inflict substantial and lasting harm on students, schools and their employees should no longer employ them as disciplinary measures.

School shaming punishments impermissibly isolate the punished child from the rest of her or his community. ${ }^{110}$ The harm of this isolation is not just immediate through the duration of the punishment; what is equally, if not more, damaging is the continued isolation that resonates after the punishment

102 Jill Wieber Lens, Justice Holmes's Bad Man and the Depleted Purposes of Punitive Damages, 101 KY. L.J. 789, 801 (2012-2013) (discussing the disconnects between retributivism and deterrence); Toni M. Massaro, Shame, Culture, and American Criminal Law, 89 MiCH. L. REV. 1880, 1918 (1991) (positing that shaming does "not have impressive specific deterrence or rehabilitative effects").

${ }^{103}$ See, e.g., Garvey, supra note 82, at 741 (discussing how utilitarianism "finds punishment justified if and only if it enhances social utility"); Gopalan, supra note 69, at 18 (arguing shaming does not work as a social sanction when the social norms at issue are not internalized).

${ }^{104}$ Amanda Harmon Cooley, The Impact of Marijuana Legalization on Youth \& the Need for State Legislation on Marijuana-Specific Instruction in K-12 Schools, 44 PEPP. L. REV. 71, 107 (2016) (discussing school exclusionary punishment's infliction of substantial present harm on schoolchildren and permanent impact on educational access and attainment).

105 Deana A. Pollard, Banning Corporal Punishment: A Constitutional Analysis, 52 AM. U. L. REv. 447, 448-49 (2002) (discussing the correlation and probable causation between child corporal punishment and numerous negative psychological and socioeconomic conditions).

106 See Clarke, supra note 18 , at 22 ("Those targeted by shaming practices often internalize stigma, coming to believe themselves to be deficient.").

107 See infra text accompanying notes 110-21.

108 See infra text accompanying notes 122-29.

109 See infra text accompanying notes $130-34$.

${ }^{110}$ Blum, supra note 100 , at 94 ("Punishment places the punished outside civilized community."). 
period. ${ }^{111}$ When children are stigmatized through shaming, they will adopt parallel beliefs about diminished self-identity and self-worth as those in the school community, thus learning and internalizing their own devaluation by the school and larger society.112 Shaming that takes place with the school community as audience exploits and creates an "anxiety that ... [includes] a fear of abandonment or isolation, usually from a social group or other community that is necessary or valuable to the individual." 113 This exploitation of anxiety that occurs in shaming punishments has a significantly harmful effect on vulnerable schoolchildren. ${ }^{114}$

School shaming punishments are also harmful as they can exacerbate existing hostility 115 or instigate previously nonexisting antisocial behaviors within the penalized student ${ }^{116}$ instead of encouraging the student to adopt positive behaviors. ${ }^{117}$ When students who are shamed in schools disagree with the validity of the punishment, they are likely to feel anger rather than remorse. ${ }^{118}$ This resentment and anger can lead to a desire to retaliate and to engage in additional, intentional rule-breaking conduct. ${ }^{119}$ Thus, school shaming punishments can incite a cyclical response of degradation, where the shaming leads to student retaliation, which results in additional shaming or other equally harmful discipline. ${ }^{120}$ The aggravation of existing hostility or the generation of new antisocial behaviors can lead to further isolation of the

111 Cara Suvall, Essay, Restorative Justice in Schools: Learning from Jena High School, 44 HARV. C.R.-C.L. L. REv. 547, 553 (2009) (discussing how alienating and isolating punishments weaken existing bonds between punished students and the school community).

112 David L. Kirp, Schools as Sorters: The Constitutional and Policy Implications of Student Classification, 121 U. PA. L. REV. 705, 734 (1973) (identifying the self-devaluation of the stigmatized child through the adoption of the same identity beliefs of others in the school).

113 Massaro, supra note 102, at 1902.

${ }^{114}$ See Garfinkel, supra note 25 , at 421 (highlighting the "ritual destruction" of shaming); Kahan, supra note 61 , at 638 (discussing the loss of peer respect and diminution of self-esteem that results from shaming).

115 Miriam Hechler Baer, Governing Corporate Compliance, 50 B.C. L. REv. 949, 1005 (2009) (noting the anger and resistance-inducing effects of punitive shaming sanctions).

116 Horwitz, supra note 70, at 148 ("[S]haming punishment[s] can induce anger or rage, resulting in further violent and antisocial behavior.").

${ }_{117}$ Maxine D. Goodman, Shame, Angry Judges, and the Social Media Effect, 63 CATH. U. L. REV. 589, 600 (2014) (arguing shame does not modify behavior positively).

118 Sandeep Gopalan, Skilling's Martyrdom: The Case for Criminalization Without Incarceration, 44 U.S.F. L. REV. 459, 485 (2010) (noting the anger, rather than remorse, shamed individuals feel when they disagree their conduct was wrongful).

${ }^{119}$ Toni M. Massaro, The Meanings of Shame: Implications for Legal Reform, 3 PSYCHOL. PUB. POL'Y \& L. 645, 648 (1997) ("Psychological accounts of shame suggest that the behavioral consequences of this emotion are unpredictable, and may include anger and a desire to retaliate against the one inflicting the shame.").

${ }^{120}$ Goodman, supra note 117 , at 605 (describing the harm of the "shame-anger cycle"). 
individual student from the community and increasingly punitive harm being directed toward the student. ${ }^{121}$

The negative outcomes associated with shaming punishments can also impact the punished student's continued success in the school and larger communities. ${ }^{122}$ Disintegrative school shaming "foster[s] exclusion and mete[s] out shame and humiliation[,] mak[ing] it easier for young people to look upon their society and their futures with suspicion and despair, rather than anticipation and hope."123 This environment of shaming can dictate whether children will drop out of the school environment ${ }^{124}$ because an educational environment that inflicts shame provides students with little inducement to remain invested in the school community. ${ }^{125}$ There may also be external pressures on the school administration to facilitate the push-out of these students. ${ }^{126}$ Further, shaming sanctions can guide the student toward harmful and perhaps criminal subcultures because they intentionally alienate the punished student from preexisting peer groups. ${ }^{127}$ Finally, as an extreme consequence, shaming can lead to the attempted or actual premature end of the student's life by suicide. ${ }^{128}$ Consequently, school shaming punishments can have a permanent negative impact on a child's educational attainment and community involvement. ${ }^{129}$

${ }^{121}$ E.g., NussBaUM, supra note 76, at 236 (discussing how shaming leads to "great alienation from society and its norms, which may well lead to greater violence" and likening shaming to "using gasoline to put out a fire").

122 See Garvey, supra note 82, at 749 (noting how shaming motivates the individual to leave the community).

${ }^{123}$ Henry A. Giroux, Youth in a Suspect Society: Coming of Age in an Era of Disposability, TRUTHOUT (May 5, 2011), http://truth-out.org/news/item/923:youth-in-asuspect-society-coming-of-age-in-an-era-of-disposability [https://perma.cc/YP45-KEUM].

${ }^{124}$ San Antonio Indep. Sch. Dist. v. Rodriguez, 411 U.S. 1, 114-15 (1973) (Marshall, J., dissenting) (finding inequitable education environments "influence a child's decision to 'enter or remain in school"' (quoting Gaston Cty. v. United States, 395 U.S. 285, 296 (1969))).

125 Gaston Cty., 395 U.S. at 296 (discussing this impact).

126 See Dean Hill Rivkin, Legal Advocacy and Education Reform: Litigating School Exclusion, 75 TENN. L. REV. 265, 280 (2008) (explaining school discipline can result in other students' parents complaining that the punished students are classroom disruptions or safety problems, which further isolates them from their peers).

127 E.g., NuSSBAUM, supra note 76, at 236 (arguing shaming "reinforce[s] a tendency to identify oneself with antisocial groups"); Note, supra note 44, at 2201 (discussing shaming's alienating impact).

128 Garvey, supra note 82, at 749 (defining the suicide effect of shaming as "selfdestruction as the subject of shame tries to rid himself [or herself] of it").

${ }^{129}$ See Markel, supra note 98, at $2174 \mathrm{n} .84$ ("[I]f the reputation of an offender is completely destroyed by [shaming], the punishment of the offenders never ends, thus vitiating an important possibility that an offender can be punished and then 'move on' in some manner productive to society."); Sarah E. Redfield \& Jason P. Nance, American Bar Association: Joint Task Force on Reversing the School-to-Prison Pipeline, 47 U. MEM. L. REV. 1, 96-97 (2016) (arguing more severe school punishments can result in a student entering the school-to-prison pipeline). 
Finally, shaming punishments can have detrimental effects into adulthood.130 These individual collateral consequences include extensive psychological, physical, and socioeconomic harms. ${ }^{131}$ Students who have been shamed in schools often are discouraged from pursuing future educational or professional opportunities because the infliction of stigma has made them believe that any investment in their own futures is futile. ${ }^{132}$ Stigma can "have a self-fulfilling criminogenic effect," resulting in adult violations of criminal law. ${ }^{133}$ Inadequate and inequitable implementation and enforcement of school shaming punishments can also play a role in later disparate outcomes like future incarceration and employment. ${ }^{134}$ Because shaming punishments inflict substantial and lasting harm on the targeted students, they are not an adequate disciplinary measure for schools. ${ }^{135}$

\section{Shaming Punishments Inflict Significant and Enduring Community Collateral Consequences}

Like exclusionary punishments ${ }^{136}$ and corporal punishments, ${ }^{137}$ school shaming punishments also can inflict significant and enduring negative

${ }^{130}$ See Kirp, supra note 112 , at 736-37 (claiming adverse school classifications manage children's and adults' lives).

131 Wayne A. Logan, Essay, Informal Collateral Consequences, 88 WASH. L. REV. 1103, 1104 (2013).

${ }^{132}$ Clarke, supra note 18 , at 42 (discussing the futility stigmatized individuals feel in making investments in their own futures).

${ }^{133}$ Logan, supra note 131 , at 1107.

${ }^{134}$ E.g., Barbara Fedders, Losing Hold of the Guiding Hand: Ineffective Assistance of Counsel in Juvenile Delinquency Representation, 14 LEWIS \& CLARK L. REV. 771, 797 (2010) (discussing the negative impact that school discipline can have upon future employment); Anders Walker, American Oresteia: Herbert Wechsler, the Model Penal Code, and the Uses of Revenge, 2009 WIS. L. REv. 1017, 1057 (2009) (highlighting a relationship between the "high number of incarcerations in the United States" and "the failure of urban public schools").

135 See Massaro, supra note 119 , at 682 (noting the grave consequences of shaming on people, like schoolchildren, who "must depend heavily on the social group for social, economic, or political support, or cannot leave the group easily").

136 See Emily Chiang, No State Actor Left Behind: Rethinking Section 1983 Liability in the Context of Disciplinary Alternative Schools and Beyond, 60 BUFF. L. REV. 615, 621-22 (2012) (identifying the school-to-prison pipeline as a negative, community collateral consequence of exclusionary punishments); Miriam Rokeach \& John Denvir, Front-Loading Due Process: A Dignity-Based Approach to School Discipline, 67 OHIO ST. L.J. 277, 279 (2006) (discussing the awareness of school disciplinary authorities of the impact of individual expulsions on the entire school community); Kimberly Davis, Comment, School House Gates: Please Remove Your Rights, 52 WILLAMETTE L. REV. 353, 369 (2016) (arguing the criminalization of school discipline has resulted from exclusionary sanctions).

137 See Patricia J. Falk, Novel Theories of Criminal Defense Based upon the Toxicity of the Social Environment: Urban Psychosis, Television Intoxication, and Black Rage, 74 N.C. L. REV. 731, 764 (1996) (identifying social learning theory, where children learn or model 
community collateral consequences. ${ }^{138}$ These include the infliction of harm on the punished student's peer group and family members, as stigma has a spillover effect. ${ }^{139}$ Also, given the relative lack of transparency and accountability attached to the imposition of shaming punishments, these disciplinary measures can result in a negative overall school disciplinary environment. ${ }^{140}$ Further, shaming punishments can damage community connections within all school constituencies and can inculcate other schoolchildren with negative norms and values. ${ }^{141}$ This inculcation of negative norms and values in schoolchildren can result in a naturalization of the cabining of rights. This naturalization disserves students as they prepare to be active members of civic democracy and has a disparate impact upon already marginalized populations within the school. ${ }^{142}$ Given these considerable community collateral consequences, schools and their employees should no longer allow shaming punishments as a method of discipline.

It is clear that the targeted student will endure negative consequences as a result of shaming punishments. ${ }^{143}$ However, shaming can have a spillover effect as well, often filtering out to stigmatize the punished student's family members or peer group. ${ }^{144}$ Further, in the Internet age, shaming punishments have the potential to extend this stigmatization of the student and his or her peers beyond the school community, where the actual punishment is imposed, into a global community, where the effects of the punishment can be exponentially magnified. ${ }^{145}$ The extension of shame beyond the punished student into the school-and perhaps global-community can be especially pernicious in that the punished student and his or her peers can be a particularly at-risk group. ${ }^{146}$

Another harmful community collateral consequence of shaming punishments is their potential to lead to an overall harsh disciplinary

the behavior they observe, as a possible causal explanation for violent behavior by children exposed to corporal punishment).

${ }^{138}$ Kenworthey Bilz \& John M. Darley, What's Wrong with Harmless Theories of Punishment, 79 CHI.-KENT L. REV. 1215, 1231 (2004) (noting how shaming penalties introduce collateral harms in the forms of the degradation of the surrounding society); see also Massaro, supra note 1.19, at 688 (noting how shaming does not lead to increased empathy or stronger community ties).

${ }^{139}$ See infra text accompanying notes 143-46.

140 See infra text accompanying notes 147-54.

141 See infra text accompanying notes 155-61.

142 See infra text accompanying notes 162-71.

143 See supra text accompanying notes 106-35.

${ }^{144}$ Kahan, supra note 61 , at 643 n.215 (identifying the spillover effect of shaming penalties).

${ }^{145}$ E.g., Benjamin F. Heidlage, Limiting the Scarlet @: Daniel J. Solove's The Future of Reputation, 83 N.Y.U. L. REV. 982, 983 (2008) (reviewing DANIEL J. SOLOVE, THE FUTURE OF REPUTATION: GOSSIP, RUMOR, AND PRIVACY ON THE INTERNET (2007)) (discussing how the Internet facilitates global public shaming).

${ }^{146}$ See Massaro, supra note 119, at 685 (arguing shaming the "least dangerous offenders ... [can] be most destructive, both to the offender and to the offender's family or other intimates who may suffer the spillover effects of the offender's public humiliation"). 
environment within the school. Shaming lacks guaranteed proportionality, ${ }^{147}$ which can result in excessive and irreversible punishment. ${ }^{148}$ This punitive environment can bleed beyond the borders of a single disciplinary use of shaming, as the resulting isolation can lead to a breakdown of empathy by schools, administrators, and teachers for the stigmatized students, their families, and their peer groups. ${ }^{149}$ Thus, shaming punishments in schools can be infectious; once used by a single teacher or administrator, they can become a toxic standard of course. ${ }^{150}$ Also, given the relative lack of transparency attached to the imposition of shaming punishments, as they are not subject to mandatory monitoring or external oversight, ${ }^{151}$ there are no accountability mechanisms for schools or their employees who shame students. ${ }^{152}$ This can lead to increasingly retributive punishments of all students within the schoolhouse, as once a school actor "stirs up public opprobrium against an offender," it can be difficult to contain how other school actors will treat the punished student and his or her peers. ${ }^{153}$ The generation of a mob mentality in the context of heightened overall shaming punishments within a school community is a particularly problematic collateral consequence of their use. ${ }^{154}$

Other harmful collateral consequences of school shaming sanctions are that they damage community connections and inculcate negative norms and values in the students who must bear witness to them. ${ }^{155}$ The shunning element of school shaming requires that the school community publicly experience the shaming punishment and communicate analogous condemnation for the

${ }^{147}$ See Jane R. Bambauer \& Toni M. Massaro, Outrageous and Irrational, 100 MINN. L. REV. 281, 347 (2015) (discussing how the Supreme Court deemed a student strip search unconstitutional "in light of its lack of proportionality to the student's [alleged] offense").

148 Gopalan, supra note 118 , at 486 (identifying the lack of architecture to ensure proportionality in shaming and its resulting potential to impose excessive, irreversible punishment).

${ }^{149}$ Clarke, supra note 18 , at 22 ("As a result of this exclusion, empathy for the stigmatized group breaks down.").

150 DOMINIQUE SMITH ET AL., BETTER THAN CARROTS OR STICKS 11 (2015) ("[T]he actions of a single teacher can negatively affect an entire school's climate: not only is the use of shame and humiliation to punish students toxic, but it's also highly infectious, spreading through a grade level or department at an alarming rate.").

151 See supra text accompanying notes $51-58$.

152 Gopalan, supra note 118 , at 486 (discussing the lack of accountability of shaming entities).

${ }^{153}$ Whitman, supra note 60 , at 1088 (discussing the lack of control that results from governmental shaming).

${ }^{154}$ NUSSBAUM, supra note 76 , at 4 (discussing how shaming punishments generate inherently unreliable and uncontrollable mob justice).

${ }^{155}$ E.g., Daniel M. Filler, Silence and the Racial Dimension of Megan's Law, 89 IowA L. REv. 1535, 1563-64 (2004) (discussing how juvenile criminal shaming sanctions harm community connections); Massaro, supra note 102, at 1902 (denoting how shaming requires an audience to witness it and to condemn the punished individual). 
punished student's behavior. ${ }^{156}$ Such required shunning harms community connections within student constituencies, as the emotional impact of shunning and shaming on bystanders, especially children, can be remarkably variant. ${ }^{157}$ This fracturing of community can lead to other negative outcomes, like peer-onpeer bullying and harassment. 158 Consequently, the community interaction requirement of school shaming punishments and its subsequent fracturing can result in an inculcation of negative norms in the students who are not being directly targeted by the shaming, but who must also endure it. ${ }^{159}$ When dealing with schoolchildren, this can result in the imposition of negative ethical values upon vulnerable participants in the process, ${ }^{160}$ providing the inverse of the education idealized in Brown. ${ }^{161}$

As a result of being forced participants in school shaming punishments, which are rights violative, students will begin to naturalize the cabining of rights because that has been their experience in schools. ${ }^{162}$ Based on this disciplinary educational environment, students become socialized "to tolerate and expect similar treatment by government officials outside of schools." 163 When the school environment incorporates rights-violative shaming conduct, these patterns can have deleterious effects on public reason, in that students will lose the civic capital to participate in democratic society. 164 This lesson is even more stratifying given the demographics of public education, which increasingly serves marginalized minority populations that are often the targets of school shaming. ${ }^{165}$ Shaming culture in schools replicates the existing social stigmas

${ }^{156}$ Massaro, supra note 102, at 1903 ("[T] he relevant audience [of shaming] must experience and must communicate a roughly common sense of outrage at, or contempt for, the sanctioned member's actions.").

157 See Mary D. Fan, Sex, Privacy, and Public Health in a Casual Encounters Culture, 45 U.C. DAVIS L. REV. 531, 590 (2011) (arguing shaming sanctions lack the ability "to be suffused with multiple meanings that can appeal across worldviews").

158 See, e.g., Mark C. Weber, Disability Harassment in the Public Schools, 43 WM. \& MARY L. REV. 1079, 1091-92 (2002) (discussing how harassment has a cumulative effect); Whitman, supra note 60, at 1059 ("[P]ublic shaming can have the dangerous consequence of stirring up riots and other mob actions.").

${ }^{159}$ See Garvey, supra note 82 , at 740 (rejecting certain shaming punishments as they "teach the wrong lesson").

160 See Gardner, supra note 90 , at 34 (discussing the Supreme Court's perspective that children are "vulnerable and dependent beings in need of protection").

161 See supra text accompanying note 34 .

162 See Weber, supra note 158, at 1091-92 ("If a harasser can verbally tease or physically intimidate a child with impunity, it reinforces a sense of power and diminishes both the perceived and real power of the child who is harassed.").

163 Jason P. Nance, Random, Suspicionless Searches of Students' Belongings: A Legal, Empirical, and Normative Analysis, 84 U. COLO. L. REV. 367, 399 (2013).

164 See John Rawls, The Idea of Public Reason Revisited, 64 U. CHI. L. REv. 765, 76566 (1997) (discussing the notions of reasonable pluralism in democracy and the core aspects of public reason).

${ }^{165}$ India Geronimo, Systemic Failure: The School-to-Prison Pipeline and Discrimination Against Poor Minority Students, 13 J.L. SoC'Y 281, 282 (2011) (identifying 
that minority children already endure. ${ }^{166}$ By being either the punished student or the punished student bystander, school shaming has an acute impact on educational equality for minority youth - especially students of color, girls, and LGBT students. Detrimental shaming punishments result in inequitable educational environments, foreclosing the students' opportunity to learn valuable lessons for later success in American society. ${ }^{167}$ Therefore, student naturalization of rights-violative disciplinary conduct by state authorities, with its disparate impact on underrepresented students, is another worrisome collateral consequence of school shaming punishments that should dictate their removal from schools.

\section{A Conclusion on the Efficacy Examination and Harm Analysis of School Shaming Punishments}

School shaming punishments should no longer be used as disciplinary methods, as they are inefficacious and harmful. Like exclusionary and corporal punishments, ${ }^{168}$ they do not meet the deterrence, rehabilitation, or reformation criteria of effective punishment theory. ${ }^{169}$ Instead, they are sanctions of Kantian retributivism, which should hold no place as disciplinary mechanisms for children and adolescents. ${ }^{170}$ Additionally, like exclusionary and corporal punishments, ${ }^{171}$ school shaming punishments result in extraordinary and

school discipline "that encourage[s] social control over marginalized populations"); Jason P. Nance, Students, Security, and Race, 63 EMORY L.J. 1, 47 (2013) (discussing the significant racial disparities among the targeted students of school discipline); David Simson, Exclusion, Punishment, Racism and Our Schools: A Critical Race Theory Perspective on School Discipline, 61 UCLA L. REV. 506, 522 (2014) (discussing the disproportionate impact that school disciplinary actions have on minority youth); Whitman, supra note 60, at 1064 (noting that "shame sanctions are in practice inflicted only on certain, peculiarly vulnerable classes of offenders").

166 Dyson, supra note 38, at 730 (discussing this replicative effect of school discipline).

${ }^{167}$ See Laura R. McNeal, Managing Our Blind Spot: The Role of Bias in the School-toPrison Pipeline, 48 ARIZ. ST. L.J. 285, 287 (2016) (arguing punitive discipline fosters educational inequity and denies minority students opportunities for future success).

168 Katherine Hunt Federle, Essay, Violence Is the Word, 37 Hous. L. REv. 97, 105 (2000) (noting that studies on the use of corporal punishments in schools have concluded they are ineffective and harmful); Thalia González, Keeping Kids in Schools: Restorative Justice, Punitive Discipline, and the School to Prison Pipeline, 41 J.L. \& EDUC. 281, 288 (2012) (noting the lack of evidence that exclusionary punishments have deterrent value).

${ }^{169}$ See generally Youngjae Lee, The Constitutional Right Against Excessive Punishment, 91 VA. L. REV. 677, 733 (2005) (describing the goals of punishment theory).

170 See Chad Flanders, Can Retributivism Be Progressive?: A Reply to Professor Gray and Jonathan Huber, 70 MD. L. REV. 166, 172 (2010) ("Kant was clear that . . . a violation of the law - whatever the law happens to be-justified retributive punishment against the lawbreaker.").

${ }^{171}$ E.g., Barbara Fedders \& Jason Langberg, School Discipline Reform: Incorporating the Supreme Court's “Age Matters" Jurisprudence, 46 LOY. L.A. L. REV. 933, 957 (2013) (outlining school exclusionary punishments' harms); Nicole Mortorano, Note, Protecting 
enduring harm for both the penalized student and the school community. ${ }^{172}$ Consequently, both an efficacy examination and a harm analysis result in a solid foundation for the rejection of school shaming punishments.

\section{A Constitutional CRitique of School Shaming Punishments}

If the efficacy and harm analyses do not provide enough persuasion for schools, teachers, and administrators to abandon shaming punishments, a constitutional critique should do so. Although student rights are notably limited ${ }^{173}$ and courts grant extensive deference to school disciplinary actions, ${ }^{174}$ shaming punishments that violate the constitutional rights of students establish a liability limit for school disciplinary authority. These punishments can give rise to monetary damages and injunctive relief in 42 U.S.C. $\$ 1983$ actions when schools and their actors violate students' First and Fourth Amendment rights. ${ }^{175}$ Further, even if these cases determine that the school entity is protected from suit due to municipal liability requirements, ${ }^{176}$ or that the school employee has qualified immunity, each judicial determination that shaming punishments are violative of the Constitution establishes valuable precedent for the future protection of students' constitutional rights in schools, either as the basis for future $\S 1983$ litigation or as a deterrence mechanism against schools and their employees from the continued use of these disciplinary methods. ${ }^{177}$ An awareness of these precedential constitutional violation findings and potential liability that can result from school shaming punishments should motivate

Children's Rights Inside of the Schoolhouse Gates: Ending Corporal Punishment in Schools, 102 GEO. L.J. 481, 502 (2014) (discussing school corporal punishments' harms).

172 See Margaret E. Johnson, A Home with Dignity: Domestic Violence and Property Rights, 2014 BYU L. REV. 1, 30 (2014) (describing how Braithwaite's shaming theory demonstrates individual and community harms).

173 Gilbert A. Holmes, Student Religious Expression in School: Is It Religion or Speech, and Does It Matter, 49 U. MiAMI L. REV. 377, 414 n.216 (1994) (discussing the Supreme Court's consistent limitation of student rights).

174 E.g., Cynthia L. Estlund, Freedom of Expression in the Workplace and the Problem of Discriminatory Harassment, 75 TEX. L. REV. 687, 772 (1997) (discussing how limitations on students' constitutional rights are justified by courts based on the need to maintain school order and discipline).

175 See Danielle Weatherby, Opening the "Snake Pit": Arming Teachers in the War Against School Violence and the Government-Created Risk Doctrine, 48 CONN. L. REV. 119, 129 (2015) (identifying $\S 1983$ litigation as one of the few legal remedies that parents and students have to redress constitutional rights violations against schools and their employees).

176 See Monell v. Dep't of Soc. Servs., 436 U.S. 658, 690 (1978) (discussing $§ 1983$ municipal liability requirements).

${ }^{177}$ See generally Richard Whitney Johnson, Trademark for Creating a Kid-Friendly Cyberplayground on the Internet, 2006 UTAH L. REV. 465, 495 (2006) (making the connection between clear precedent and effective deterrence). 
educational entities and educators to no longer inflict these types of discipline. ${ }^{178}$

\section{A. The Nature of Students' Constitutional Rights and Judicial Deference to School Disciplinary Authority}

Education bears a substantial relationship to federal constitutional rights and guarantees. ${ }^{179}$ State educational institutions and employees are bound to perform within the limits of the Constitution. ${ }^{180}$ However, there has been limited success in aligning the complex challenges of children to their treatment by the state in constitutional doctrine. ${ }^{181}$ This limited success can be attributed, in part, to the extraordinary deference that courts have afforded to schools, administrators, and teachers in their disciplinary authority over students. ${ }^{182}$

Schools and their employees have been given broad latitude when it comes to student punishments. ${ }^{183}$ Even in the rights-expansive Tinker v. Des Moines Independent Community School District decision, ${ }^{184}$ the Supreme Court recognized its repeated emphasis on "the need for affirming the comprehensive authority of the States and of school officials, consistent with fundamental constitutional safeguards, to prescribe and control conduct in the schools."185 This control discourse has been a focal point in each of the Court's subsequent decisions that has examined school disciplinary conduct. ${ }^{186}$ The Court's

178 See, e.g., Stuart L. Leviton, Is Anyone Listening to Our Students? A Plea for Respect and Inclusion, 21 FLA. ST. U. L. REV. 35, 53 (1993) ("Government and school administrators are not benevolent dictators. They must be limited by some guiding principle recognizing students' constitutional rights in light of a balance between the reasonable educator and the reasonable student.").

${ }^{179}$ San Antonio Indep. Sch. Dist. v. Rodriguez, 411 U.S. 1, 111 (1973) (Marshall, J., dissenting) (discussing the fundamental importance of education and its close connection to core constitutional values).

${ }^{180}$ New Jersey v. T.L.O., 469 U.S. 325, 336-37 (1985) (discussing how schools and school officials are bound by the commands of the First and Fourth Amendments); W. Va. State Bd. of Educ. v. Barnette, 319 U.S. 624, 637 (1943) (providing that schools and school actors must "perform within the limits of the Bill of Rights").

181 See Brown, supra note 36, at 992 (discussing this alignment problem).

182 E.g., Ingraham v. Wright, 430 U.S. 651, 681-82 (1977) (granting deference to the discretion of school authorities in assessing school discipline).

${ }^{183}$ Naomi Harlin Goodno, How Public Schools Can Constitutionally Halt Cyberbullying: A Model Cyberbullying Policy that Considers First Amendment, Due Process, and Fourth Amendment Challenges, 46 WAKE FOREST L. REV. 641, 680 (2011) ("Courts generally defer to the school's judgment of what level of punishment is appropriate. The court may weigh public policy interests in determining whether the punishment is too harsh, but unless the facts fall heavily on the side of harm to the student, courts will accept the form of punishment that a school chooses." (footnote omitted)).

184 Tinker v. Des Moines Indep. Cmty. Sch. Dist., 393 U.S. 503, 511 (1969).

$185 \mathrm{Id}$. at 507.

186 Amanda Harmon Cooley, Controlling Students and Teachers: The Increasing Constriction of Constitutional Rights in Public Education, 66 BAYLOR L. REv. 235, 247 
recognition in 1975 that "[s]ome modicum of discipline and order is essential if the educational function is to be performed"187 evolved in only ten years to a "substantial need of teachers and administrators for freedom to maintain order in the schools." 188 Essentially, the Court has established a highly deferential standard regarding the constitutionality of school punishments that provides that teachers cannot educate their students without first building a strong foundation of discipline and order. 189

So, the unique characteristics of schools result in the circumscription of student rights. ${ }^{190}$ Specifically, the Court has found that First and Fourth Amendment rights "are different in public schools than elsewhere."191 The Court has rooted this finding on its control discourse, which has asserted the primacy of the state's need for supervision and control of schoolchildren over the free exercise of students' constitutional rights. ${ }^{192}$ Consequently, public school students' constitutional rights are markedly limited within the schoolhouse gate, ${ }^{193}$ based on a judicial justification that maintaining order in an educational environment requires greater controls over children than in other contexts. ${ }^{194}$

Even though students' First and Fourth Amendment rights are "different" (which appears to be a judicial euphemism for barely existent) ${ }^{195}$ in schools and substantial deference has been afforded to schools, teachers, and administrators with regard to their disciplinary authority over students, such "authority is not unlimited." 196 The Supreme Court has determined that these limits are exceeded

(2014) (arguing “Tinker's lasting precedent ... is its control discourse"); Amy B. Cyphert, Addressing Racial Disparities in Preschool Suspension and Expulsion Rates, 82 TENN. L. REV. 893, 908 (2015) (discussing the Supreme Court's repeated emphasis on the state's comprehensive authority to "control conduct in the schools").

187 Goss v. Lopez, 419 U.S. 565, 580 (1975) (emphasis added).

188 New Jersey v. T.L.O, 469 U.S. 325, 341 (1985) (emphasis added).

${ }^{189} \mathrm{See}$ Bd. of Educ. of Indep. Sch. Dist. No. 92 v. Earls, 536 U.S. 822, 831 (2002) (discussing the Court's deference to school disciplinary authority).

${ }^{190}$ See Morse v. Frederick, 551 U.S. 393, 405 (2007) (reaffirming that students' constitutional rights are "circumscribed "in light of the special characteristics of the school environment"' (quoting Tinker, 393 U.S. at 506)).

191 Vernonia Sch. Dist. 47K v. Acton ex rel. Acton, 515 U.S. 646, 656 (1995); see also Kristi L. Bowman, Public School Students ' Religious Speech and Viewpoint Discrimination, 110 W. VA. L. REV. 187, 220 (2007) (discussing the Court's "school is different" ideology in student constitutional rights cases).

192 See Acton, 515 U.S. at 655.

193 Cooley, supra note 186, at 238 (discussing how the Court's control discourse has resulted in the "dramatic curtailment of the scope of student constitutional rights").

${ }^{194}$ Earls, 536 U.S. at 831.

195 See Erwin Chemerinsky, The Deconstitutionalization of Education, 36 LOY. U. CHI. L.J. 111, 112, 135 (2004) (arguing that students' First and Fourth Amendment rights have been almost completely decimated due to the Court's "almost unlimited deference to school officials").

${ }^{196}$ New Jersey v. T.L.O., 469 U.S. 325, 385 (1985) (Stevens, J., concurring in part and dissenting in part). 
with the imposition of school discipline that violates students' constitutional rights, even as circumscribed as they are. ${ }^{197}$ In Tinker, the Court stated: "In our system, state-operated schools may not be enclaves of totalitarianism. School officials do not possess absolute authority over their students. Students in school as well as out of school are 'persons' under our Constitution. They are possessed of fundamental rights which the State must respect . . .."198 As to the First Amendment, the Court has made clear that state actors cannot abridge students' free speech rights. ${ }^{199}$ As to the Fourth Amendment, the Court has recognized that students still retain a legitimate expectation of privacy despite the need for public schools to maintain discipline. ${ }^{200}$ Consequently, when disciplinary authority exceeds constitutional limits, courts should not defer to schools and their actors. ${ }^{201}$ In these instances, it is appropriate for schools and their employees to be held liable for the constitutional violations of their students' rights through 42 U.S.C. $§ 1983$ actions. ${ }^{202}$

\section{B. School Shaming Punishments, Students' Constitutional Rights, and 42 U.S.C. $\$ 1983$ Liability}

Given the intensely pernicious nature of rights-violative school shaming punishments, it appears that they have set an important bar for a growing judicial unwillingness to defer to school disciplinary authority. ${ }^{203}$ Consequently, schools should no longer use shaming punishments, as courts will not afford them disciplinary deference where these sanctions result in violations of students' First or Fourth Amendment rights that might give rise to $\S 1983$ liability. ${ }^{204}$ Although the bulk of scholarly analysis of student constitutional rights has been pervasively bleak, ${ }^{205}$ this Article's normative argument is

${ }^{197}$ See Tinker v. Des Moines Indep. Cmty. Sch. Dist., 393 U.S. 503, 512 (1969) ("The vigilant protection of constitutional freedoms is nowhere more vital than in the community of American schools." (quoting Shelton v. Tucker, 364 U.S. 479, 487 (1960))).

$198 \mathrm{Id}$. at 511.

${ }^{199}$ Id. at 513 ("The Constitution says that Congress (and the States) may not abridge the right to free speech. This provision means what it says.").

${ }^{200}$ T.L.O., 469 U.S. at 338 (finding that despite the "difficulty of maintaining discipline in the public schools today, the situation is not so dire that students in the schools may claim no legitimate expectations of privacy").

201 See, e.g., Barbara Kritchevsky, Making Sense of State of Mind: Determining Responsibility in Section 1983 Municipal Liability Litigation, 60 GEO. WASH. L. REV. 417, 453 (1992) (discussing how abusive constitutional-violative conduct should lead to governmental liability).

202 Highhouse v. Wayne Highlands Sch. Dist., 205 F. Supp. 3d 639, 645 (M.D. Pa. 2016) (discussing $\S 1983$ remedies for constitutional rights deprivations).

203 See Black, supra note 26, at 866 ("Constitutional principles and logical application of them prohibit disciplinary practices that are lacking in reason, logic, judgment, or justification.").

204 See infra text accompanying notes 346-48, $444-45$.

${ }^{205}$ See, e.g., Derek W. Black, The Congressional Failure To Enforce Equal Protection Through the Elementary and Secondary Education Act, 90 B.U. L. REV. 313, 320 (2010) 
actually an optimistic one for the validation and protection of student rights in schools and a cautionary one for schools, administrators, and teachers in terms of their disciplinary limits. It will use case examples to illustrate how certain school shaming punishments can exceed (and can actually be judicially deemed to exceed) the constitutional limits of the considerable deference that has been extended to schools and their employees by the courts in disciplinary matters. In these examples, the school entity and school employees have been held to have engaged in rights-violative conduct via the shaming punishment, which could potentially support the imposition of monetary, declaratory, or injunctive relief. $^{206}$ Even in cases where ultimate liability was not extended to all of the defendants under the concepts of municipal liability or qualified immunity, all hope is certainly not lost. This is because the establishment of the rightsviolative nature of shaming punishments paves the way for the vindication of future student constitutional rights litigation or for the abolition of shaming punishments as a self-correction by schools and their employees who do not want to be subject to potential liability, ${ }^{207}$ to endure the attendant negative publicity of school shaming lawsuits, ${ }^{208}$ or to violate the constitutional rights of their students any longer. 209

(noting how Congress has also acted "as though students' [constitutional] rights ... do not exist"); Chemerinsky, supra note 195, at 134-35 (arguing the extreme judicial deference to school disciplinary authority has resulted in "deconstitutionalized education," specifically within the context of First and Fourth Amendment rights); Diana R. Donahoe, Strip Searches of Students: Addressing the Undressing of Children in Schools and Redressing the Fourth Amendment Violations, 75 Mo. L. REV. 1123, 1168 (2010) (outlining the judicial dilution of students' Fourth Amendment rights to the extent that "they are almost nonexistent"); MaryRose Papandrea, Student Speech Rights in the Digital Age, 60 FLA. L. REV. 1027, 1084 (2008) (noting how many of the Supreme Court's decisions have "suggested that students have diminished or even nonexistent constitutional rights"); Nadine Strossen, Essay, Students' Rights and How They Are Wronged, 32 U. RiCH. L. REV. 457, 458 (1998) (deeming Tinker a "high-water mark for students' rights" with "some sad back-sliding . . . since then"). Admittedly, this analysis has included the author's own scholarship. See Cooley, supra note 186 , at 289 (describing the status of student constitutional rights as "stark").

206 See Pamela S. Karlan, The Paradoxical Structure of Constitutional Litigation, 75 FORDHAM L. REV. 1913, 1918 (2007) ("[Section 1983] [d]amages litigation offers an opportunity not only to compensate individuals who have been injured by unconstitutional conduct, but to refine constitutional law as well.").

${ }^{207}$ See Myriam E. Gilles, In Defense of Making Government Pay: The Deterrent Effect of Constitutional Tort Remedies, 35 GA. L. REV. 845, 848 (2001) (arguing there is a deterrent effect when damages are imposed on state employees in $\S 1983$ lawsuits).

${ }^{208}$ Richard Frankel, Regulating Privatized Government Through § 1983, 76 U. СН. L. REV. 1449, 1491 (2009) (identifying the negative publicity of $\S 1983$ liability as the primary motivating factor in governmental remedial actions).

${ }^{209}$ See, e.g., Amanda M. Rose \& Richard Squire, Essay, Intraportfolio Litigation, 105 Nw. U. L. REV. 1679, 1685 n.19 (2011) (discussing how education about litigation risks to avoid liability can influence future actions made by employees). 


\section{Students' Constitutional Rights and 42 U.S.C. $\S 1983$ Liability}

Under 42 U.S.C. $\S 1983$, plaintiffs are granted a federal remedy for deprivations of their constitutional rights by people acting under the color of state law. ${ }^{210}$ Section 1983 actions are often difficult cases for student plaintiffs to win $^{211}$ because there are three preliminary postural hurdles that must be cleared to obtain a positive judgment in these constitutional tort lawsuits. ${ }^{212}$ These hurdles are sovereign immunity, the requirements for municipal liability, and qualified immunity.

First, the defendant must not qualify for Eleventh Amendment sovereign immunity. ${ }^{213}$ Sovereign immunity insulates state governments and their instrumentalities, deemed to be "arms of the State," from liability in 42 U.S.C. $\S 1983$ lawsuits. ${ }^{214}$ Conversely, local governing bodies are "persons" under $\S 1983,215$ which means they can be sued for monetary, declaratory, or injunctive relief in these federal lawsuits. ${ }^{216}$ Local school boards, school districts, and school corporations are typically found not to meet the sovereign immunity threshold of being an arm of the state and instead to be local government bodies that are subject to $\S 1983$ actions, thereby not qualifying for sovereign immunity. ${ }^{217}$

21042 U.S.C. $\S 1983$ (2012) (providing the elements for a civil federal constitutional action).

${ }^{211}$ Matthew J. Silveira, Comment, An Unexpected Application of 42 U.S.C. $\$ 14141$ : Using Investigative Findings for $\$ 1983$ Litigation, 52 UCLA L. REV. 601, 604 (2004) (noting a $\S 1983$ claim "is easier brought than won").

212 Eric Berger, The Collision of the Takings and State Sovereign Immunity Doctrines, 63 WASH. \& LEE L. REV. 493, 574 n.405 (2006) (discussing Eleventh Amendment sovereign immunity analysis in $\S 1983$ actions); Matthew J. Cron et al., Municipal Liability: Strategies, Critiques, and a Pathway Toward Effective Enforcement of Civil Rights, 91 DENV. U. L. REV. 583, 606 (2014) (describing the Monell requirements as a hurdle for establishing $\S 1983$ municipal liability); Nancy Leong \& Aaron Belzer, Enforcing Rights, 62 UCLA L. REV. 306, 325 (2015) (classifying qualified immunity as a $\S 1983$ obstacle).

213 See Lynn A. Baker \& Ernest A. Young, Essay, Federalism and the Double Standard of Judicial Review, 51 DUKE L.J. 75, $102 \mathrm{n} .133$ (2001) (noting how sovereign immunity bars states from being sued for money damages without their consent in $\S 1983$ litigation).

${ }^{214}$ Mount Healthy City Sch. Dist. Bd. of Educ. v. Doyle, 429 U.S. 274, 280-81 (1977) (holding arms of the state are immune to $\S 1983$ suits); Berger, supra note 212 , at $499 \mathrm{n} .13$ (noting the state has sovereign immunity as it is not a person under $\S 1983$ ).

215 See Alan K. Chen, The Ultimate Standard: Qualified Immunity in the Age of Constitutional Balancing Tests, 81 IOWA L. REV. 261, 339 n.371 (1995) (discussing how local government bodies are not entitled to sovereign immunity for $\S 1983$ actions).

216 Monell v. Dep't of Soc. Servs., 436 U.S. 658, 690 (1978) (discussing $§ 1983$ municipal liability).

217 See Doyle, 429 U.S. at 280 (concluding that "a local school board . . . is more like a county or city than it is like an arm of the State"); Parker v. Franklin Cty. Cmty. Sch. Corp., 667 F.3d 910, 926 (7th Cir. 2012) (finding that "as local governmental units, the school corporations are clearly 'persons' within the ambit of $\S 1983$ ”). 
Second, if the school entity defendant is deemed to be a local governmental body that is potentially subject to a $\S 1983$ lawsuit, ${ }^{218}$ Monell municipal liability must be established, whereby the constitutional deprivation must be pursuant to an official policy or custom. ${ }^{219}$ Essentially, the concept of respondeat superior does not apply to $\S 1983$ actions. ${ }^{220}$ The Supreme Court held in Monell $v$. Department of Social Services that:

Local governing bodies, therefore, can be sued directly under $\S 1983$ for monetary, declaratory, or injunctive relief where, as here, the action that is alleged to be unconstitutional implements or executes a policy statement, ordinance, regulation, or decision officially adopted and promulgated by that body's officers. Moreover, although the touchstone of the $\S 1983$ action against a government body is an allegation that official policy is responsible for a deprivation of rights protected by the Constitution, local governments, like every other $\S 1983$ "person," by the very terms of the statute, may be sued for constitutional deprivations visited pursuant to governmental "custom" even though such a custom has not received formal approval through the body's official decisionmaking channels. ${ }^{221}$

It was also determined in Pembaur v. City of Cincinnati, a plurality opinion after Monell, that municipal liability can be established when the unconstitutional actions are executed by a municipal official who has been delegated with final policymaking authority by the local governing body. ${ }^{222}$ This Monell requirement has placed an additional burden on plaintiffs to establish municipal liability in $\S 1983$ lawsuits. ${ }^{223}$ When schools discipline students with rightsviolative shaming punishments pursuant to formal policies, a student plaintiff will easily be able to demonstrate a foundation for municipal liability. ${ }^{224}$ But in

218 See Gershon M. Ratner, A New Legal Duty for Urban Public Schools: Effective Education in Basic Skills, 63 TEX. L. REV. 777, 810 n.117 (1985) ("Municipalities and local school districts ... do not have sovereign immunity and are subject to damage awards for constitutional violations pursuant to 42 U.S.C. $\$ 1983$.").

219 See Monell, 436 U.S. at 690-91.

220 See Jeffrey W. Stempel, Tending to Potted Plants: The Professional Identity Vacuum in Garcetti v. Ceballos, 12 NEV. L.J. 703, 722 (2012) (discussing the inapplicability of respondeat superior in $\S 1983$ actions).

${ }^{221}$ Monell, 436 U.S. at 690-91 (footnotes omitted).

222 Pembaur v. City of Cincinnati, 475 U.S. 469, 480-83 (1986).

223 See Laura Oren, Immunity and Accountability in Civil Rights Litigation: Who Should Pay?, 50 U. PITT. L. REv. 935, 996 (1989) (noting how the Monell policy or custom requirement makes it "increasingly difficult to establish municipal liability" in $\S 1983$ actions).

224 Teressa E. Ravenell, Blame It on the Man: Theorizing the Relationship Between \$ 1983 Municipal Liability and the Qualified Immunity Defense, 41 SETON HALL L. REV. 153,165 (2011) (discussing municipal liability that results from the enforcement of a rightsviolative, formal written policy). 
cases where the shaming punishments are not inflicted pursuant to a formal policy, establishing school entity liability will be much more difficult. ${ }^{225}$

Finally, for an individual school actor, like an administrator or teacher, to be held liable in a $\S 1983$ action, the student's deprived constitutional rights must be clearly established. 226 Otherwise, the individual school actor will be immune from suit under the doctrine of qualified immunity. ${ }^{227}$ There are two prongs for whether a government official is entitled to qualified immunity: (1) whether the alleged facts constitute a constitutional violation, and (2) whether the constitutional right was clearly established at the time of the alleged violation. ${ }^{228} \mathrm{~A}$ constitutional right can be clearly established even when a case presents novel factual circumstances, because there is no requirement that previous cases be fundamentally similar. ${ }^{229}$ As long as previous decisions gave a reasonable warning that the disputed conduct violated a constitutional right, that right can meet the clearly established prong in the denial of qualified immunity. 230

Courts have the discretion to decide the ordering of the two prongs in their qualified immunity analyses based on the cases' circumstances. ${ }^{231}$ In many school disciplinary cases, individual school administrators or teachers have been allocated qualified immunity, 232 "generally on a finding that the constitutional rights at issue were not clearly established." 233 This shielding qualified immunity doctrine for government officials is indicative of the culture of deference that courts afford to schools and their employees in the arena of student discipline. ${ }^{234}$

${ }^{225}$ See Fred Smith, Local Sovereign Immunity, 116 COLUM. L. REv. 409, 414 (2016) ("[T] he [Monell] municipal causation requirement nonetheless often inoculates local governments from accountability, including for conduct that would render them liable for violations of state law." (footnote omitted)).

${ }^{226}$ Sam Kamin, An Article III Defense of Merits-First Decisionmaking in Civil Rights Litigation: The Continued Viability of Saucier v. Katz, 16 GEO. MASON L. REV. 53, 89 (2008) (discussing qualified immunity's requirements).

227 James E. Pfander, Essay, Resolving the Qualified Immunity Dilemma: Constitutional Tort Claims for Nominal Damages, 111 CoLUM. L. REv. 1601, 1613 (2011) (discussing $\S 1983$ qualified immunity).

${ }^{228}$ Saucier v. Katz, 533 U.S. 194, 201 (2001) (articulating the two-prong inquiry for qualified immunity).

${ }^{229}$ Hope v. Pelzer, 536 U.S. 730, 741 (2002).

230 United States v. Lanier, 520 U.S. 259, 269 (1997).

231 Pearson v. Callahan, 555 U.S. 223, 236 (2009).

232 See Joanna C. Schwartz, How Governments Pay: Lawsuits, Budgets, and Police Reform, 63 UCLA L. REV. 1144, 1152 (2016) (noting how "qualified immunity make[s] it difficult for plaintiffs to prevail even when their rights have been violated").

${ }^{233}$ B.V. ex rel. T.V.v. Smith-Green Cmty. Sch. Corp., 807 F. Supp. 2d 767, 786 (N.D. Ind. 2011).

${ }^{234}$ See Eric Berger, Individual Rights, Judicial Deference, and Administrative Law Norms in Constitutional Decision Making, 91 B.U. L. REV. 2029, 2053 (2011) (discussing qualified immunity's impact). 
In sum, a student whose constitutional rights have been violated by being shamed in school will face considerable burdens in obtaining a final judgment of monetary, declaratory, or injunctive relief against both the school entity and the school actors based on 42 U.S.C. $\S 1983$ requirements. ${ }^{235}$ However, these burdens are not insurmountable, and there is a growing body of precedent that establishes how shaming punishments are constitutional rights violative. ${ }^{236}$ So, even if there is a determination of no municipal liability or qualified immunity in these cases, school entities and their employees should be made aware that each judicial examination of shaming punishments that results in a finding of rights-violative conduct is a step toward clearly established constitutional rights that will provide additional examples of school entity municipal liability and that will eventually no longer sustain qualified immunity extensions to administrators and teachers. This developing precedent should deter schools, teachers, and administrators from engaging in punitive school shaming punishments to avoid future liability and its corresponding negative publicity. ${ }^{237}$ More importantly, schools and their employees should end their use of shaming as a method of discipline as these entities and individuals should not choose to violate the constitutional rights of their students. ${ }^{238}$

\section{School Shaming Punishments, Students' First Amendment Rights, and 42 U.S.C. § 1983 Liability}

Schools that inflict shaming punishments for the exercise of student speech rights expose themselves to potential liability via a $\S 1983$ action premised on a claimed violation of the First Amendment. A prevalent example of this type of shaming punishment is the forced apology for protected speech, whereby the school requires a public apology that stigmatizes the student for "behavior [that] is perceived to have violated a social norm." 239 Although there have been some judicial decisions that have determined a compelled apology sanction for speech is not a violation of a student's First Amendment rights, ${ }^{240}$ there has been a

235 Rachel L. Jensen \& Hayley Macon, Sexual Harassment in Education, 1 GEO. J. GENDER \& L. 435, 450 n.103 (2000) (noting how Monell makes it difficult for students to prevail against school districts in $\S 1983$ litigation); Carlos Manuel Vázquez, Eleventh Amendment Schizophrenia, 75 NOTRE DAME L. REV. 859, 876-78 (2000) (discussing qualified immunity's burden on $\S 1983$ plaintiffs).

236 See infra Part III.B.1-2.

${ }^{237}$ See, e.g., Rebecca L. Brown, Essay, Tradition and Insight, 103 YALE L.J. 177, 222 (1993) (highlighting the educative value of tradition in the context of constitutional inquiries for past and future conduct).

${ }^{238} \mathrm{See}$ id. at 180 (arguing "the Constitution should be viewed as part of a body of tradition that can teach present and future generations the principles that will allow society not merely to change, but to mature").

239 Grinvald, supra note 43 , at 665 .

240 This is not to say these were proper constitutional adjudications. See, e.g., Corder v. Lewis Palmer Sch. Dist., 566 F.3d 1219, 1232 (10th Cir. 2009) (finding the school district's compelling a student to apologize to the school community for a non-pre-approved reference 
growing body of $\S 1983$ case law that has determined these shaming punishments are violative of students' speech rights. ${ }^{241}$ Even among those cases that have found conversely, though, there has been a recognition of the harshly stigmatizing nature of such apologies as school disciplinary measures. ${ }^{242}$

Compelled apologies are especially problematic when such punishments are inflicted in retribution for the truthful reporting of criminal or tortious behavior; ${ }^{243}$ when they are imposed for the valid exercise to not engage in other compelled speech; 244 when they are enforced against speech based on vague, overbroad, and inherently shaming-based disciplinary policies that prohibit dishonorable or immoral behavior; 245 or when they are based on a custom of persistent unconstitutional misconduct. ${ }^{246}$ When forced apologies are issued as shaming sanctions in these circumstances, schools, teachers, and administrators should be sued and held liable in 42 U.S.C. $\S 1983$ actions. Because of this potential for liability and because these sanctions abridge students' speech rights, schools and their employees should no longer use compelled apologies as shaming punishments to keep order and discipline. ${ }^{247}$

When forced apologies are used by schools and their employees as a retributive shaming sanction for students who report criminal or tortious behavior of other students, courts should and will find them to be violative of students' First Amendment rights. For example, in Seamons ex rel. Seamons $v$.

to Jesus Christ in her valedictory speech to receive her diploma was not a violation of the student's First Amendment rights as the punishment was "reasonably related to the School District's [legitimate] pedagogical concerns"); Lowery v. Euverard, 497 F.3d 584, 596 (6th Cir. 2007) (determining a high school football coach did not violate the speech rights of student players he dismissed from the team when they refused to apologize for drafting or signing a petition for the school to terminate the coach's employment based on his humiliation and abuse per the Tinker reasonable-forecast-of-substantial-disruption standard); Wildman ex rel. Wildman v. Marshalltown Sch. Dist., 249 F.3d 768, 772 (8th Cir. 2001) (determining the school district and employees were entitled to summary judgment on the student's First Amendment claim for a required apology as a punishment for writing an insubordinate letter about her basketball coach); Kicklighter v. Evans Cty. Sch. Dist., 968 F. Supp. 712, 719-21 (S.D. Ga. 1997) (relying on the Tinker control discourse to determine that a school district and principal were entitled to summary judgment on a student's First Amendment claim because "to require a simple apology [in front of an entire class] for truculent and disruptive in-school behavior [for retorting to a teacher to 'Check the Declaration of Independence'] falls well within the ambit of an institution's balanced 'comprehensive authority"'), aff'd sub nom. Kicklighter v. Evans Cty. Sch., 140 F.3d 1043 (11th Cir. 1998) (mem.).

241 See supra text accompanying notes $210-17$.

${ }^{242}$ See, e.g., Wildman, 249 F.3d at 772 ("The parties perhaps could have achieved with minimal creativity and flexibility a solution more amicable or less humiliating to the student.").

243 See infra text accompanying notes $256-70$.

244 See infra text accompanying notes $271-301$.

245 See infra text accompanying notes $300-28$.

246 See infra text accompanying notes $329-45$.

${ }^{247}$ Student consent is not a justification for these types of apologies, as consent "is valid only if it is uncoerced." Garvey, supra note 82 , at 761 . 
Snow, Brian Seamons, a high school football player, was assaulted by a group of his teammates, including two of the four team captains, in the school locker room. ${ }^{248}$ After showering, Brian was forcibly restrained by these teammates and bound to a towel rack with highly adhesive athletic tape. ${ }^{249} \mathrm{~A}$ fifth teammate then brought one of Brian's former girlfriends into the locker room to witness the hazing. ${ }^{250}$ After reporting the assault to the police, the school principal, and the football coach, Brian and his parents were informed by the coach that the assailants would not be disciplined or removed from the team. ${ }^{251}$ Four days after the assault, Brian decided to remain on the team, and the coach relayed everything had been resolved to the principal. ${ }^{252}$

However, that same afternoon, prior to a game, one of the involved team captains demanded that Brian apologize to the team for reporting the hazing as a condition to remain on the team. ${ }^{253}$ The coach told Brian that "he needed to 'forgive and forget and apologize' to the team captains," which Brian refused to do.254 The coach then instructed Brian to think about it over the weekend, because he would not play with the team until he apologized to the captains. ${ }^{255}$ Brian's father alerted the principal, and the next week, after Brian communicated to the coach that he was not going to apologize, the coach told Brian that "he was 'sick of [his] attitude, sick of [his] father's attitude,' and that he was off of the team." 256

The school's football season was cancelled the next day, and Brian and his family filed a $\S 1983$ lawsuit against the school district and the coach that alleged his First Amendment speech rights were violated. ${ }^{257}$ The district court granted the defendants summary judgment based on a finding that Brian's constitutional rights had not been violated, deemed the school district not to have municipal liability, and granted the coach qualified immunity. 258

On appeal, the Tenth Circuit Court of Appeals reversed these judgments of the district court. ${ }^{259}$ In reviewing the lower court's decision in the light most favorable to Brian, 260 the court determined that there were disputed factual issues as to whether the coach asked Brian to apologize to the team captains, whether the intended scope of the request was to force an apology for reporting the assault, and whether Brian's refusal to apologize was a significant factor in

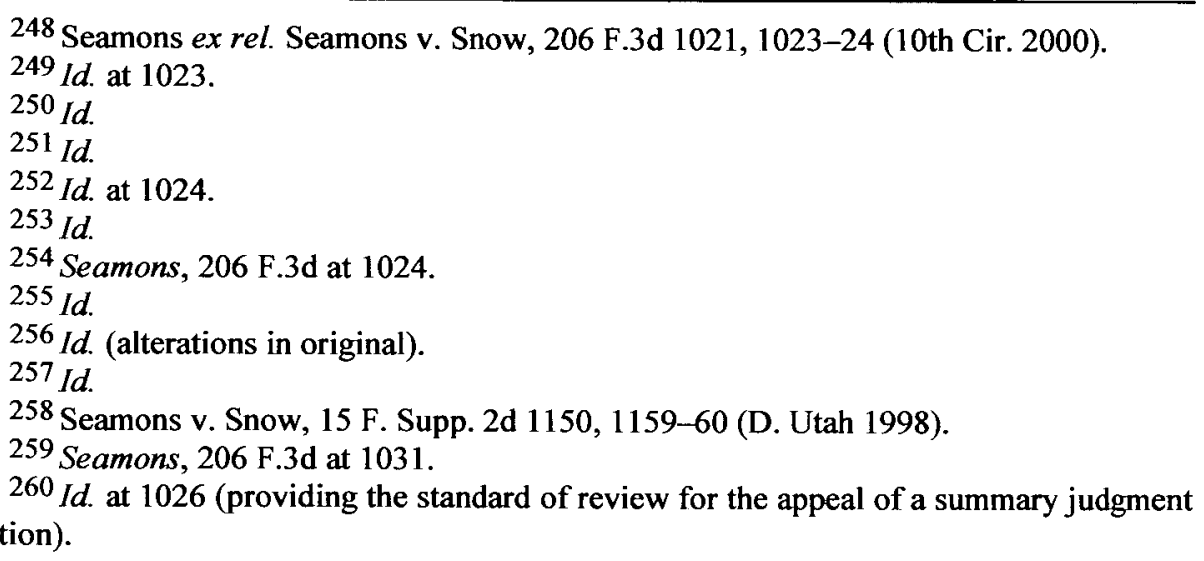


his dismissal from the team. ${ }^{261}$ In this analysis, the court noted that there were enough clear inferences and evidence for each of these factors to support Brian's First Amendment claim and to entitle him to his requested day in court. ${ }^{262}$

With respect to the school district's potential municipal liability, the court adopted the Pembaur approach and determined that the school district could be held liable for the coach's actions because the school district had delegated final policymaking authority to the coach for decisions regarding the school's football team. ${ }^{263}$ The Tenth Circuit also reversed the district court's grant of qualified immunity to the coach. ${ }^{264}$ The court determined that Brian's constitutional speech rights-not to be penalized for nondisruptive, nonobscene, and non-school-sponsored speech - were clearly established at the time that the coach conditioned his continued membership on the football team on a forced apology for reporting the assault. ${ }^{265}$ Because the court determined that a reasonably competent official would be aware of the law regarding these rights, the coach was not entitled to qualified immunity for his punitive actions. ${ }^{266}$

Consequently, the Seamons decision sets an important precedent that students cannot be shamed into forced apologies in retaliation for the truthful reporting to school authorities of criminal or tortious conduct, because these sanctions are violative of students' First Amendment rights, ${ }^{267}$ as circumscribed as they are in the school environment. ${ }^{268}$ Additionally, the case appropriately illustrates a broader reading of school districts' municipal liability in $\S 1983$ lawsuits through the application of Pembaur and how school officials will not be shielded by the deferential qualified immunity doctrine for the violation of students' clearly established speech rights.

When compelled apologies are used by schools and their employees as retributive shaming punishments for students' valid exercise of their rights not to engage in other compelled speech, courts should and will find such sanctions to be violative of students' First Amendment rights. For example, in Holloman ex rel. Holloman v. Harland, Michael Holloman, a high school senior, brought a 42 U.S.C. $§ 1983$ lawsuit claiming that his First Amendment rights were violated when he was punished by the school principal and his economics and government teacher with a forced apology and a paddling for raising his fist in silent protest, rather than reciting the Pledge of Allegiance with his classmates,

261 Id. at $1027-28$.

262 Id. at $1028,1031$.

263 Id. at $1029,1031$.

$264 \mathrm{Id}$. at $1030-31$.

265 Seamons, 206 F.3d at 1030.

266 Id. at $1030-31$.

${ }^{267}$ See John F. Wirenius, The Last Word-Status Conflicts, Individual Autonomy, and Freedom of Speech, 23 HAMLINE L. REV. 394, 422 (2000) (arguing compelled apologies violate fundamental norms of constitutional law).

${ }^{268}$ See Michael Sheetz, Casenote, Qualified Immunity and Privacy-The Fifth Circuit Finds That Students Have No Clearly Established Right to Confidentiality in Their Sexual Orientation, 67 SMU L. REv. 219, 222 (2014) (discussing the Supreme Court's curtailment of students' constitutional rights). 
during the daily flag salute. ${ }^{269}$ The required daily recitation of the pledge was pursuant to a district policy. 270 On the day before the incident with Michael, John Hutto, another student in Michael's class, had remained silent during the pledge with his hands in his pockets, had been criticized for it by the teacher in front of the class, had been threatened by the principal to have it reported to his Air Force Academy recruiter and recommending congressperson, and had been ordered by the principal to apologize to the teacher and the class. ${ }^{271}$ That afternoon, the principal warned students that anyone who refused to say the pledge would be punished. ${ }^{272}$ The next morning, John apologized to the teacher and the class. ${ }^{273}$

That same morning, Michael silently raised his fist during the pledge. ${ }^{274}$ Following this, Michael's teacher chastised him in front of the entire class, and Michael's principal told him that he had failed to be taught "responsibility, morals[,] and values." 275 The principal penalized him with three days of detention and a compelled apology to the teacher and the class as a condition to receive his diploma that week. ${ }^{276}$ However, because there were not enough days prior to graduation, Michael was paddled by the principal in front of the teacher instead. 277

The district court granted the principal and teacher summary judgment based on qualified immunity. ${ }^{278}$ It also granted the school board summary judgment based on a determination that Michael had failed to sufficiently allege a constitutional rights violation and that it was not subject to municipal liability under Monell. ${ }^{279}$ On appeal, the Eleventh Circuit reversed the district court's grant of summary judgment in its entirety. ${ }^{280}$

With regard to the principal and teacher's claims to qualified immunity on Michael's compelled-speech claim, the court determined that the 1943 West Virginia State Board of Education v. Barnette case established the right of public school students to be free from compelled speech in the forced recitation of the pledge. ${ }^{281}$ Because the court determined that evidence in the record

${ }^{269}$ Holloman ex rel. Holloman v. Harland, 370 F.3d 1252, 1260-61 (11th Cir. 2004).

270 Id. at 1261-62 (implementing an Alabama statute that required the daily recitation of the pledge as part of the character education program for all local school boards, in the context, however, of another state statute that provided students shall not be compelled to say the pledge).

271 Id. at 1260.

272 Id.

273 Id.

274 Id. at 1261.

275 Holloman, 370 F.3d at 1261.

276 Id.

277 Id.

278 Id.

279 Id. at 1260.

280 Id. at 1265 .

281 Holloman, 370 F.3d at 1268 (citing W. Va. State Bd. of Educ. v. Barnette, 319 U.S. 624, 642 (1943)). 
supported Michael's claim he was disciplined for failing to recite the pledge, the court found that the teacher and principal's alleged acts violated his First Amendment rights. ${ }^{282}$ In this finding, the court stressed that the teacher's verbal censure of Michael in front of the class was an embarrassing and humiliating punishment designed to dissuade him from exercising his right to be free from governmental compelled speech: "Given the gross disparity in power between a teacher and a student, such comments_-particularly in front of the student's peers - coming from an authority figure ... whose words carry a presumption of legitimacy, cannot help but have a tremendous chilling effect on the exercise of First Amendment rights." 283

Further, the court determined that Michael's constitutional right to engage in this conduct had been clearly established since Barnette and that any reasonable person would have known that this discipline would impermissibly violate this right. ${ }^{284}$ Therefore, the Eleventh Circuit determined that neither the teacher nor the principal was entitled to qualified immunity on Michael's compelled-speech claim. ${ }^{285}$

The court also determined that neither the principal nor the teacher was entitled to qualified immunity on Michael's expressive-conduct speech claim. ${ }^{286}$ In doing so, the court analogized Michael's silent fist raise to the black armbands of Tinker in finding that this act could constitute either protected pure speech or expressive conduct. ${ }^{287}$ Even working within the construct of limited student speech rights and the Tinker control discourse, ${ }^{288}$ the court stated that "in assessing the reasonableness of regulations that tread upon expression, we cannot simply defer to the specter of disruption or the mere theoretical possibility of discord, or even some de minimis, insubstantial impact on classroom decorum." 289 Consequently, because the court determined that Michael's action did not meet the Tinker standard regarding a reasonable forecast of substantial and material disruption, it was entitled to First Amendment protection. 290

The court similarly rejected the teacher's claims that Michael's discipline was appropriate based on other students disagreeing with his actions, finding this was irrelevant to the analysis. ${ }^{291}$ To let these student reactions be determinative of the constitutional inquiry would be "to sacrifice freedom upon the alter of order, and allow the scope of our liberty to be dictated by the

282 Id. at 1268 .

283 Id. at 1269.

284 Id.

$285 / d$.

$286 \mathrm{Id}$. at 1270.

${ }^{287}$ Holloman, 370 F.3d at 1270.

${ }^{288}$ See id. at 1271-72 (describing the constitutional context relating to First Amendment rights in schools).

289 Id.

$290 \mathrm{Id}$. at 1274.

${ }^{291} \mathrm{Id}$. at 1274-75. 
inclinations of the unlawful mob."292 As to the principal's actions, the court had a strict admonishment as well: "Principals have the duty to maintain order in public schools, but they may not do so while turning a blind eye to basic notions of right and wrong."293 The court determined that Michael's right to engage in his conduct was clearly established under the Tinker standard that would be reasonably understood by "the defendants - who holds [sic] themselves out as educators." 294 Therefore, the principal and the teacher were not entitled to qualified immunity on this claim. 295

As to the school board's assertion that it was entitled to summary judgment under Monell, the court determined that the school board's policy that required the daily inclusion of the pledge was a sufficient policy directive to support the municipal liability of the school board. ${ }^{296}$ The court reversed the grant of summary judgment to the school board, finding that the board could be held liable for Michael's compelled speech claim. ${ }^{297}$ Additionally, the court determined that the school board could be held liable for the speech-rightsviolative acts of the principal as it had delegated him final policymaking authority on school discipline in this factual context, given the impending graduation, the required apology, and the completed paddling. ${ }^{298}$ As a result, the court reversed the district court's summary judgment for the school board. ${ }^{299}$

Consequently, the Holloman decision is another important precedential case that instructs schools, administrators, and teachers that they cannot penalize students with shaming by way of compelled apologies (or with stigmatizing verbal censure or mob mentality chilling) for the exercise of their lawful right to refrain from government compelled speech. These school attempts to compel speech for exercising a right to refrain from compelled speech are exemplary of the pernicious nature of forced apologies as shaming punishments. Additionally, this case, like the Seamons case, appropriately illustrates a broader reading of school districts' municipal liability in $\S 1983$ lawsuits through the application of the policy or delegation of final policymaking approach and provides another example of how school officials will not be shielded with qualified immunity for the abusive violation of students' clearly established speech rights.

School entities and their employees should also be held liable when they require forced apologies as shaming punishments for protected student speech pursuant to vague and overbroad disciplinary policies that prohibit dishonorable or immoral behavior-policies that are inherently shaming based. For example, in B.V. ex rel. T.V. v. Smith-Green Community School Corp., two female high school students, sixteen-year-old T.V. and fifteen-year-old M.K., brought a

\footnotetext{
292 Id. at 1275.

293 Holloman, 370 F.3d at 1276.

294 Id. at 1278.

295 Id. at 1265.

296 See id. at 1262, 1290-91.

297 Id. at 1269, 1291.

298 See id. at 1292-93.

${ }^{299}$ Holloman, 370 F.3d at 1295.
} 
$\S 1983$ claim against their school district corporation and high school principal after they were suspended from participating in extracurricular activities for a calendar year for posting sophomoric photographs featuring lollipops and toys resembling sex organs to their private, password-protected social media accounts. ${ }^{300}$ All the photographs were taken and were posted to the Internet in private, off-campus homes and not during the academic school year. ${ }^{301}$ The plaintiffs were informed their suspensions were a consequence of a violation of a student handbook policy that prohibited "act[ing] in a manner in school or out of school that brings discredit or dishonor upon yourself or your school."302 The students were also informed by the principal that, under the policy, their punishment could be reduced if they visited a counselor three times and thereafter apologized individually to the school's all-male athletic board, ${ }^{303}$ with which they complied. 304

Subsequently, the students - through their parents-sued claiming these shaming punishments were a violation of their First Amendment speech rights. ${ }^{305}$ Granting the plaintiffs' summary judgment motion on this claim and determining that the school's punishment was violative of their First Amendment rights, ${ }^{306}$ the court concluded that the students could not be punished for speech that did not meet the substantial disruption or reasonable forecast of substantial disruption standard of Tinker, ${ }^{307}$ no matter how "juvenile and silly" the speech was. ${ }^{308}$ In doing so, the court expressly recognized the limits of judicial deference to school disciplinary authority:

With all respect to the important and valuable function of public school authorities, and the considerable deference to their judgment that is so often due, "[i]t would be an unseemly and dangerous precedent to allow the state, in the guise of school authorities, to reach into a child's home and control his/her actions there to the same extent that it can control that child when he/she participates in school sponsored activities."309

${ }^{300}$ B.V. ex rel. T.V. v. Smith-Green Cmty. Sch. Corp., 807 F. Supp. 2d 767, 771-74, 785 (N.D. Ind. 2011).

301 Id. at $771-72$.

302 Id. at 774 .

${ }^{303}$ Id ; see also Ali Elkin, Judge: Indiana Teens' Racy Social Media Photos Are Protected Speech, CNN (Aug. 24, 2011), http://www.cnn.com/2011/US/08/19/racy.pictures. protected.speech/index.html [https://perma.cc/8VKW-RVYS].

${ }^{304}$ B.V., 807 F. Supp. $2 d$ at 774.

$305 \mathrm{Id}$. at 771 .

306 Id. at 785 .

${ }^{307}$ Id. at $783-84$.

308 Id. at 775 ("No message of lofty social or political importance was conveyed, but none is required.").

$309 \mathrm{Id}$. at $784-85$ (alteration in original) (quoting Layshock ex rel. Layshock v. Hermitage Sch. Dist., 650 F.3d 205, 216 (3d Cir. 2011) (en banc)). 
In addition to determining that the students' First Amendment rights were violated by these shaming punishments as a matter of law, 310 the court denied the school corporation's motion for summary judgment that it was entitled to Eleventh Amendment sovereign immunity. ${ }^{311}$ The school corporation argued it had sovereign immunity because it was an arm of the state, which shielded it from $\S 1983$ damages in federal courts. ${ }^{312}$ The court disagreed, noting that the Supreme Court had determined that local school boards are often not entitled to sovereign immunity in these actions. ${ }^{313}$

The question of municipal liability as a potential defense for the school corporation was not disputed in this case because the shaming punishments were propagated pursuant to the policy that prohibited student conduct that brings "discredit or dishonor" upon the student or the school.314 As demonstrated by the record, the students were expressly told that they were suspended from extracurricular activities per the policy and that a forced apology would reduce their punishment under the policy. 315 Therefore, Monell's provision that plaintiffs can sue local governing bodies in $\S 1983$ lawsuits where the alleged unconstitutional action executes an official policy was satisfied here, and the school corporation could not avoid liability for its shaming punishments this way. ${ }^{316}$

Although the court determined that the school corporation could not avoid $\S 1983$ liability under the concepts of sovereign immunity or municipal liability restrictions, ${ }^{317}$ it did find that the school principal was entitled to qualified immunity as these First Amendment rights "were not clearly established."318 Because the Supreme Court had not considered the extent to which, if any, school officials could regulate off-campus, Internet student speech, the court determined that there was uncertainty about the amount of constitutional deference that could be afforded to a school official in this factual setting. ${ }^{319}$ This resulted in the grant of qualified immunity to the principal. ${ }^{320}$

The court ended its discussion by finding that the school policy that allows discipline for student conduct that brings "dishonor" or "discredit" upon the school or student "is so vague and overbroad as to violate the [First Amendment

310 B.V., 807 F. Supp. 2d at 790.

311 Id. at 791 .

$312 \mathrm{Id}$. at 785 .

313 Id. (citing Mount Healthy City Sch. Dist. Bd. of Educ. v. Doyle, 429 U.S. 274, $280-$

81 (1977)). The Seventh Circuit subsequently held that school corporations are local government units and not arms of the state, thereby making them subject to suit as $\S 1983$ persons. See Parker v. Franklin Cty. Cmty. Sch. Corp., 667 F.3d 910, 927, 929 (7th Cir. 2012).

314 B.V., 807 F. Supp. $2 d$ at 774.

315 Id. at $773-74$.

316 Monell v. Dep't of Soc. Servs., 436 U.S. 658, 690-91 (1978).

${ }^{317}$ B.V., 807 F. Supp. $2 d$ at 774.

318 Id. at 790 .

319 See id. at 786.

$320 \mathrm{Id}$. 
of the] Constitution." 321 In making this determination, the court stressed that " $[t]$ he notion of good character inherent in [the term of 'discredit'] introduces a nebulous degree of value judgment" and that such "[i] ssues of character and values involve such a broad spectrum of reasonable interpretation (but also strongly-held disagreement) as to be insufficiently conclusive for a disciplinary standard." 322 Consequently, the court's vagueness and overbreadth determination supported issuing an injunction against the enforcement of the policy. 323

This judicial dissection of school punishments imposed per vague and overbroad morality policies supports the rejection of these shaming punishments. When compelled apologies are used in this way, where students are forced to be contrite for sexually expressive behavior that does not meet the Tinker standard for conduct that "would 'materially and substantially interfere with the requirements of appropriate discipline in the operation of the school," 324 they can implicate harmful notions of student slut shaming. ${ }^{325}$ This type of forced apology, as shaming punishment, communicates that these students "committed a bad act that is worthy of criticism" and should be condemned by school authority figures. ${ }^{326}$ Such nebulous value judgments cannot take the place of established First Amendment jurisprudence, and in the B.V. ex rel. T.V. case, the court appropriately drew the line in terms of its unwillingness to defer to the school's disciplinary authority.

When schools issue forced apology shaming punishments for students engaging in nondisruptive speech that is nebulously deemed to be dishonorable and discreditable, they are violating the First Amendment and should be held liable for it. The B.V. ex rel. T.V. decision is an important case that helps to establish this proposition. Further, as forced apology case law for Internet speech develops, teachers and administrators should not and no longer will be shielded from liability with qualified immunity when they instigate such punishments. Although numerous shaming advocates have justified forced apologies as a cost-effective means of deterring rules-violative conduct, exacting retribution, and reinforcing social norms, ${ }^{327}$ forced apologies in this context violate students' First Amendment rights, as circumscribed as they are at schools. ${ }^{328}$

321 ld. at 790 .

322 Id. at 789 .

323 B. V., 807 F. Supp. $2 d$ at 789.

324 Tinker v. Des Moines Indep. Cmty. Sch. Dist., 393 U.S. 503, 509 (1969) (quoting Burnside v. Byars, 363 F.2d 744, 749 (5th Cir. 1966)).

325 See LiJia Gong \& Alina Hoffman, Note, Sexting and Slut-Shaming: Why Prosecution of Teen Self-Sexters Harms Women, 13 GEO. J. GENDER \& L. 577, 583-87 (2012) (discussing this phenomenon in schools).

326 Id. at 583 .

${ }^{327}$ See White, supra note 22, at 1268 (listing shaming advocates' rationales for compelled apologies).

328 See Stephen E. Henderson, Hijacked from Both Sides-Why Religious Extremists and Religious Bigots Share an Interest in Preventing Academic Discourse on Criminal 
Finally, schools and their employees should be held liable for shaming forced apologies for protected speech when they are based on a custom of persistent unconstitutional misconduct. For example, in S.S. ex rel. R.S. v. Minnewaska Area School District No. 2149, R.S., a twelve-year-old sixth grader, was forced to apologize to an adult hall monitor after she posted a negative comment about the hall monitor, accessible only by her designated friends, to her Facebook account from her home outside of school hours ${ }^{329} \mathrm{Her}$ comment was: " $\Pi$ hate] a Kathy person at school because [Kathy] was mean to me." 330 Upon viewing this comment, the principal punished R.S. by forcing her to apologize to the hall monitor and by giving her a detention for rude and discourteous behavior that was memorialized in her disciplinary record. 331 Thereafter, R.S.'s mother brought suit on behalf of her daughter for a violation of her First Amendment rights pursuant to 42 U.S.C. $§ 1983$ against the school district and its superintendent. ${ }^{332}$ In response to this complaint, the defendants filed a motion to dismiss, in which the school district claimed it was not subject to municipal liability and the superintendent claimed he was entitled to qualified immunity. ${ }^{333}$

The district court denied the school district's motion to dismiss on its municipal liability claim, ${ }^{334}$ finding the plaintiffs had sufficiently alleged the punishment of R.S. for out-of-school Internet speech was pursuant to a custom based on an allegation of multiple students facing similar punishments. ${ }^{335}$ This allegation supported a "finding that the school officials ... were motivated by, and conducting themselves in accordance with, a 'continuing, widespread, persistent pattern of unconstitutional misconduct."'336 Because municipal liability can be premised on a local governing body's custom under Monell, ${ }^{337}$ the court determined the school district could not be shielded from municipal liability. 338

The court likewise denied the superintendent's motion to dismiss based on qualified immunity. ${ }^{339}$ First, it found the complaint sufficiently alleged facts to support a finding that R.S.'s punishment was a violation of her First Amendment

Jurisprudence Based on the First Principles of Christianity, 37 IDAHO L. REV. 103, 129 (2000) ("The State has no right to coerce an apology ... ."); see also Sheetz, supra note 268, at 222 (discussing the Supreme Court's curtailment of students' constitutional rights).

329 S.S. ex rel. R.S. v. Minnewaska Area Sch. Dist. No. 2149, 894 F. Supp. 2d 1128, 1133 (D. Minn. 2012).

$330 \mathrm{Id}$. (alterations in original).

331 Id

332 Id. at $1133,1136$.

333 See id. at 1136.

334 Id. at 1138.

335 See S.S., 894 F. Supp. $2 \mathrm{~d}$ at 1138. 1999))

${ }^{336}$ Id. (quoting Mettler ex rel. Mettler v. Whitledge, 165 F.3d 1197, 1204 (8th Cir.

337 See Monell v. Dep't of Soc. Servs., 436 U.S. 658, 690-91 (1978).

338 See S.S., 894 F. Supp. $2 \mathrm{~d}$ at 1138.

339 Id. at 1141. 
rights. ${ }^{340}$ To do so, the court classified the alleged speech as neither a true threat nor "so egregious as to pose a serious safety risk or other substantial disruption in that environment." 341 Finally, unlike the B.V. ex rel. T.V. case, the court determined that although " $[\mathrm{t}]$ he standard for showing a clearly established right is certainly stringent," the complaint sufficiently alleged R.S. had a clearly established right to her off-campus, Internet speech. ${ }^{342}$ Because a reasonable official would understand that punishing R.S.'s speech, which was "in the heartland of protected nonviolent and nondisruptive out-of-school speech," would transgress her First Amendment rights, the motion for qualified immunity was denied. ${ }^{343}$

The S.S. ex rel. R.S. case provides an important precedent that establishes that schools and their employees do not have unlimited authority to discipline the nondisruptive, off-campus Internet speech of their students via shaming compelled apologies. ${ }^{344}$ Further, it establishes a relatively expansive reading of municipal liability for school entities in terms of finding a Monell custom and an equally expansive reading of a lack of entitlement to qualified immunity for individual administrators by applying Tinker principles to the digital communications of students. ${ }^{345}$ Consequently, schools and their employees should reject adopting a customary approach to these types of shaming forced apologies for protected Internet speech based on the possibility of ensuing $\S 1983$ liability.

The receding away from traditional deference to schools' disciplinary authority in these compelled apology cases demonstrates the particularly egregious nature of adult educators attempting to force speech on students as a punishment for the students' protected speech. ${ }^{346}$ These shaming sanctions trigger Tinker's totalitarianism tipping point, ${ }^{347}$ resulting in rights-recognitive precedent for students who are punished with forced apologies for exercising their First Amendment rights in schools, as circumscribed as they are. ${ }^{348}$ Additionally, these cases demonstrate broader readings of municipal liability for school entities and narrower applications of the qualified immunity doctrine for individual school actors. Consequently, in addition to rejecting compelled

${ }^{340} I d$.
341 Id. at 1140.
342 Id. at 1141.
${ }^{343}$ Id.
344 S.S. 894 F. Supp. 2 d at 1141.
345 Id.
346 See Kristin Henning, What's Wrong with Victims' Rights in Juvenile Court?:

Retributive Versus Rehabilitative Systems of Justice, 97 CALIF. L. REV. 1107, 1167 (2009) (discussing the impropriety of situations where "adults appear to 'gang up' on the child or attempt to "shame' the child into ... apology").

${ }^{347}$ Tinker v. Des Moines Indep. Cmty. Sch. Dist., 393 U.S. 503, 511 (1969).

348 See Erwin Chemerinsky, Teaching that Speech Matters: A Framework for Analyzing Speech Issues in Schools, 42 U.C. DAVIS L. REV. 825, 825-26 (2009) (discussing the limited nature of students' speech rights). 
apologies as disciplinary measures based on their inefficaciousness and harm, ${ }^{349}$ schools, administrators, and teachers should no longer inflict these stigmatizing punishments as they face potential liability for violating their students' First Amendment rights when they do so.

\section{School Shaming Punishments, Students' Fourth Amendment Rights, and 42 U.S.C. $\$ 1983$ Liability}

Schools that inflict shaming punishments on students via unreasonable and invasive searches expose themselves to potential liability through 42 U.S.C. $\S 1983$ actions premised on claimed violations of the Fourth Amendment. Given the connections between privacy and shame, ${ }^{350}$ strip searches that are used as shaming sanctions for schoolchildren can be particularly malignant and intrusive. ${ }^{351}$ Student strip searches meet the definitional parameters of shaming punishments because they are stigmatizing disciplinary measures, designed to punish or shame, ${ }^{352}$ that are inflicted on the student in view of some members of the school community-whether they be other adult employees or peers, ${ }^{353}$ where the student has allegedly violated a school disciplinary rule and attendant social norms. ${ }^{354}$

Since the Supreme Court's determination in Safford Unified School District \#1 v. Redding, which held that a student's Fourth Amendment rights were violated by a school strip search, ${ }^{355}$ courts have demonstrated an increased unwillingness to defer to this exercise of school disciplinary authority. ${ }^{356}$ This has generated a growing body of $\S 1983$ case law that has determined these shaming punishments violate students' privacy rights. ${ }^{357}$ Although Redding has

349 See Brent T. White, Saving Face: The Benefits of Not Saying I'm Sorry, 72 LAW \& CONTEMP. PROBS. 261, 268 (2009) (discussing the nondeterrent nature and psychological harms of coerced apologies).

${ }^{350}$ Massaro, supra note 119 , at 665 ("The concept of privacy seems to be bound to shame.").

351 See, e.g., Christopher Slobogin, The World Without a Fourth Amendment, 39 UCLA L. REV. 1, 95 (1991) (discussing the intrusiveness of shaming governmental actions like "searches for infractions of school disciplinary rules").

352 See id. (classifying school searches as government actions where the purpose is "to punish or shame").

353 See Safford Unified Sch. Dist. \#1 v. Redding, 557 U.S. 364, 369 (2009) (describing how an assistant principal required a student to be strip searched by the school nurse and a school administrative assistant); Katz \& Mazzone, supra note 51, at 363 (noting how some school strip searches are conducted in front of student peers).

${ }^{354}$ See generally Grinvald, supra note 43, at 665 (discussing the definitional criteria of shaming punishments).

355 Redding, 557 U.S. at 368.

356 See infra text accompanying notes $392-443$; see also Aaron Sussman, Comment, Learning in Lockdown: School Police, Race, and the Limits of Law, 59 UCLA L. REV. 788, 833 (2012) (identifying a baseline of judicial deference to schools' disciplinary authority in students' Fourth Amendment 42 U.S.C. $§ 1983$ lawsuits).

357 See infra text accompanying notes $392-443$. 
been criticized for not going far enough in protecting these rights and for granting the searching school officials qualified immunity, ${ }^{358}$ the case has actually resulted in a clearer establishment of students' Fourth Amendment rights in the context of strip searches than critics originally expected and in an increased trend of courts not bestowing qualified immunity upon administrators and teachers who strip search students. ${ }^{359}$ When strip searches are issued as shaming sanctions, schools, teachers, and administrators should be sued and held liable in 42 U.S.C. $\S 1983$ actions. Because of this potential liability for rights-violative conduct and because these sanctions abridge students' privacy rights, schools and their employees should no longer use strip searches as shaming punishments to keep order and discipline. 360

The constitutional critique of strip searches logically begins with Redding, in which the Supreme Court found that a thirteen-year-old honors student's Fourth Amendment rights were violated when she was strip searched by school officials who had reasonable suspicion that she possessed prescription and overthe-counter drugs. ${ }^{361}$ In this case, Savana Redding was suspected of violating her middle school's rules regarding possession without school permission of any drug on school grounds. ${ }^{362}$ Based on another student's report, Savana was removed from her math class by the assistant principal and directed to his office, where he inquired if she knew anything about four prescription-strength ibuprofens and one over-the-counter pain reliever. ${ }^{363}$ After Savana denied knowledge of the pills, her belongings and clothes were searched, with no contraband being found. 364

Then, at the direction of the school's assistant principal, the school nurse and a school administrative assistant instructed Savana "to pull her bra out and to the side and shake it, and to pull out the elastic on her underpants, thus exposing her breasts and pelvic area to some degree."365 The shaming strip search had a tremendously negative impact on Savana, who attested:

The school officials' viewing of [her] naked body was 'the most humiliating experience" of her life. . . Embarrassed and scared, Savana held her head down throughout the strip search "so that they could not see that I was about to cry." . . . Throughout this ordeal, Savana was not permitted to call her

358 See, e.g., Donahoe, supra note 205, at 1150-57 (discussing Redding's shortcomings); Nance, supra note 165 , at $12 \mathrm{n} .64$ (stating the Redding qualified immunity decision makes it difficult for students to prevail on Fourth Amendment school search claims).

359 See infra text accompanying notes 401-02, 408, 415, 422-23.

360 See Donahoe, supra note 205, at 1157 (arguing "strip searches are so invasive they should not be used even if a school possesses a 'special need"'); Katz \& Mazzone, supra note 51 , at 368 (arguing that because strip searches are "qualitatively different from other searches" they should not be allowed in schools).

361 Safford Unified Sch. Dist. \#1 v. Redding, 557 U.S. 364, 368 (2009).

362 Id. at 371 .

363 Id. at 368 .

364 Id.

365 Id at 369. 
mother. . . . Following the incident, Savana, an honor-roll student at SMS, transferred to a different school. ${ }^{366}$

The strip searchers did not find any pills. ${ }^{367}$ Savana's mother subsequently filed a $\S 1983$ action against the school district, the assistant principal, the school nurse, and the administrative assistant. ${ }^{368}$

In its analysis, the Supreme Court classified this as a strip search that would require elevated and distinct elements of justification to be reasonable based on "both subjective and reasonable societal expectations of personal privacy."369 The Court found that Savana's "subjective expectation of privacy against such a search is inherent in her account of it as embarrassing, frightening, and humiliating." 370 The Court affirmed the reasonableness of this expectation by comparing it to the consistent experiences of other similarly searched schoolchildren, where the flagrant intrusiveness of the strip searches was intensified by their adolescent vulnerability. 371 This reasonable expectation was further affirmed by the Court finding that multiple communities have banned school strip searches as being per se unreasonable because they are inherently degrading. 372

Although the Court did not agree that all student strip searches are per se unreasonable under the Fourth Amendment, ${ }^{373}$ it did find this particular search was a constitutional violation, as the administrator's suspicion of wrongdoing did not match the level of intrusion of the strip search. ${ }^{374}$ There was no sign of danger to other students from the strength or quantity of these pills, and there was no basis for believing that Savana was hiding them in her underwear. ${ }^{375}$ In doing so, the Court expressly rejected the school's proffered justification that it is a universal truth that "students ... hid[e] contraband in or under their clothing," as such a categorically intrusive strip search cannot be based on general possibilities and "nondangerous school contraband does not raise the specter of stashes in intimate places." 376 Consequently, the Court determined the search was unreasonable and Savana's Fourth Amendment rights were violated. ${ }^{377}$ The Court then remanded the case for determination of whether the school district could be held municipally liable under Monell because the Ninth

366 Brief for Respondent at 3, Safford Unified Sch. Dist. \#1 v. Redding, 557 U.S. 364

(2009) (No. 08-479), 2009 WL 852123, at *3 (citations omitted).

367 Redding, 557 U.S. at 369.

368 See id.

$369 \mathrm{Id}$. at 374 .

$370 \mathrm{Id}$. at $374-75$.

371 Id. at 375 .

372 Id.

373 See Redding, 557 U.S. at 375 ("The indignity of the search does not, of course, outlaw it ....").

${ }^{374} I d$. ("Here, the content of the suspicion failed to match the degree of intrusion.").

375 Id. at $376-77$.

$376 \mathrm{Id}$. at 376 (alterations in original).

377 See id. at 379. 
Circuit had not addressed the issue. ${ }^{378}$ In concluding its analysis, the Court made clear that "before a search can reasonably make the quantum leap from outer clothes and backpacks to exposure of intimate parts," there must be "reasonable suspicion of danger or of resort to underwear for hiding evidence of wrongdoing." 379

Although the Court held that Savana's privacy rights were violated, it also granted the assistant principal, school nurse, and administrative assistant qualified immunity for these claims. ${ }^{380}$ This finding was premised on divergent lower court decisions on how the New Jersey v. T.L.O. standard, which informs school employees to limit a school search's intrusiveness "in light of the age and sex of the student and the nature of the infraction," 381 applied to school strip searches. ${ }^{382}$ Consequently, the Court determined that these nonuniform judicial views raised doubt as to whether it was clearly established that such a search would violate the Fourth Amendment. ${ }^{383}$ Although the Court granted qualified immunity to the Redding school employees, it also articulated that clearly established rights do not require that "the very action in question [has] previously been held unlawful [because] [t]he unconstitutionality of outrageous conduct obviously will be unconstitutional." 384

Redding has been validly criticized for its application of the T.L.O. reasonable suspicion standard to student strip searches ${ }^{385}$ and for its qualified immunity finding. ${ }^{386}$ Although Redding would have been much more protective of student rights had it held that school strip searches are per se unreasonable or so intrusive that they should require the more stringent probable cause standard, ${ }^{387}$ the case established a significant precedent by connecting rightsviolative student strip searches to the inappropriate and unconstitutional use of shaming as a school disciplinary measure. Specifically, the Court found that " $[t]$ he meaning of such a search, and the degradation its subject may reasonably feel, place a search that intrusive in a category of its own demanding its own

378 Id

379 Redding, 557 U.S. at 377.

380 Id. at 381 .

381 New Jersey v. T.L.O., 469 U.S. 325, 342 (1985).

382 See Redding, 557 U.S. at 378.

${ }^{383}$ See id. at $378-79$.

384 Id. at 377 (citation omitted) (quoting Wilson v. Layne, 526 U.S. 603, 615 (1999)); see also Murphy ex rel. K.H. v. Morgan, 914 F.2d 846, 851 (7th Cir. 1990).

${ }^{385}$ See Martin R. Gardner, Strip Searching Students: The Supreme Court's Latest Failure To Articulate a "Sufficiently Clear" Statement of Fourth Amendment Law, 80 Miss. L.J. 955, 956-57 (2011) (arguing Redding does not provide sufficiently clear guidance).

386 See Eve Brensike Primus, Disentangling Administrative Searches, 111 Colum. L. REV. 254, 300-01 (2011) (predicting Redding's qualified immunity finding will lead to more unjustified student searches).

${ }^{387}$ See Donahoe, supra note 205, at 1150 (arguing Redding does not go far enough to protect student rights as the Court should have adopted a probable cause standard for school strip searches). 
specific suspicions." 388 So, despite Redding's palpable shortcomings, one of its redemptive legacies has been its suggestion that courts have an "increased willingness ... to evaluate-rather than simply assume-the impact of investigations and punishments on students in determining whether the rights of those students warrant restriction." 389 This suggestion has been taken up by multiple lower courts in their $\S 1983$ determinations that strip searches violate students' Fourth Amendment rights and that the searching employees should not be shielded from liability with qualified immunity. ${ }^{390}$ This trending judicial unwillingness to defer to school disciplinary authority when assessing student strip searches is a positive one, ${ }^{391}$ and it should deter schools and their employees from their continued use as shaming disciplinary sanctions.

Post-Redding, there has been a growing body of case law that has determined school strip searches can violate students' Fourth Amendment rights and these are clearly established rights that negate the entitlement of school officials to qualified immunity. ${ }^{392}$ This line of cases demonstrates a much clearer establishment of students' Fourth Amendment rights when they are forced to endure a strip search than originally expected by some of Redding's critics, ${ }^{393}$ but it also demonstrates the abusive and egregious use of these shaming punishments currently being utilized on schoolchildren. The cases illustrate how courts will no longer defer to the disciplinary authority of the schools when they inflict strip searches as shaming punishments needlessly in front of the student's peers; 394 when they arbitrarily impose them in circumstances that are not based on impending danger to the school community; ${ }^{395}$ when they are conducted by a school employee of the opposite sex; $;^{396}$ and when they exploit particular vulnerabilities of the student. ${ }^{397}$ Consequently, these are appropriate holdings that establish a clear precedent for

${ }^{388}$ Redding, 557 U.S. at 377.

${ }^{389} \mathrm{Kim}$, supra note 55 , at 876.

390 See, e.g., Highhouse v. Wayne Highlands Sch. Dist., 205 F. Supp. 3d 639, 649 (M.D. $\mathrm{Pa}$. 2016) (finding qualified immunity did not shield school actors from individual liability for a strip search for stolen money based on Redding's clear establishment of students' constitutional rights in this context).

${ }^{391}$ See Caitlin E. Borgmann, The Constitutionality of Government-Imposed Bodily Intrusions, 2014 U. ILL. L. REV. 1059, 1096 (2014) (noting the Supreme Court in Redding "tempered its deference to school officials with attentiveness to a strip search's impact on students").

392 E.g., Hayward v. Salem City Bd. of Educ., No. CV 14-5200 (JBS/AMD), 2016 WL 4744132 , at $* 5$ (D.N.J. Sept. 12, 2016) (denying a school resource officer's motion for summary judgment on a $\S 1983$ failure to intervene claim where he was present along with the male vice principal in a small office, in which a strip search that exposed the breasts of the searched student to the searching female school employee took place).

393 See supra notes 385-86.

394 See infra text accompanying notes 398-403.

395 See infra text accompanying notes 404-09.

396 See infra text accompanying notes 410-16.

397 See infra text accompanying notes 417-24. 
discontinuing the use of strip searches as disciplinary methods in American schools.

When schools and their employees inflict strip searches as shaming punishments needlessly in front of the student's peers, they violate the students' Fourth Amendment privacy rights. For example, in Dawson ex rel. D.H. $v$. Clayton County School District, based on a suspicion of drug possession, a twelve-year-old seventh grader, D.H., was subjected to a fully nude strip search by the male assistant principal in the presence of the school resource officer and three of his student peers. ${ }^{398}$ The Eleventh Circuit Court of Appeals determined that the searching administrator was not entitled to qualified immunity for the violation of the student's Fourth Amendment rights. ${ }^{399}$ Relying on Redding's determination that "adolescent vulnerability intensifies the patent intrusiveness of the exposure," 400 the court determined that the assistant principal's decision to "forc[e] D.H. to strip naked in front of his peer ... exposed D.H. to an unnecessary level of intrusion that rendered the search excessive in scope and, therefore, [the strip search was] unconstitutional."401 Next, the court appropriately concluded that:

[A] reasonable official in [the administrator's] position would not have believed that requiring D.H. to strip down to his fully naked body in front of several of his peers was lawful in light of the clearly established principle that a student strip search, even if justified in its inception, must be "reasonably related to the objectives of the search and not excessively intrusive in light of the age and sex of the student and the nature of the infraction."402

Consequently, the court appropriately determined that the administrator was not entitled to qualified immunity from liability for this constitutionally violative strip search. 403

When schools and their employees arbitrarily impose shaming strip searches in circumstances that are not based on impending danger to the school community, they violate students' Fourth Amendment rights. For example, in Highhouse v. Wayne Highlands School District, Ryan Highhouse, a sixteenyear-old high school student, was forced to strip down to his underwear by his teacher and school vice principal, who then pulled at his underwear's elastic, exposing his anal and pubic areas, under a belief that he stole $\$ 250$ from another student during gym class. ${ }^{404}$ Heavily relying upon Redding's degradation

398 Dawson ex rel. D.H. v. Clayton Cty. Sch. Dist., 830 F.3d 1306, 1310-12 (11th Cir. 2016).

${ }^{399} I d$. at 1320.

400 Safford Unified Sch. Dist. \#1 v. Redding, 557 U.S. 364, 375 (2009).

401 Dawson, 830 F.3d at 1318.

402 Id. (quoting Redding, 557 U.S. at 370).

403 See id. at 1319.

${ }^{404}$ Highhouse v. Wayne Highlands Sch. Dist., 205 F. Supp. 3d 639, 643 (M.D. Pa. 2016). 
analysis of student strip searches, ${ }^{405}$ the court determined the Redding rule for reasonable strip searches was not met. ${ }^{406}$ Specifically, it found that currency does not pose the potential to inflict harm or damage to school community members and that the defendants "had no reason to believe that students hide money in their underwear." 407 Consequently, the court determined that Ryan had sufficiently pled the basis for a Fourth Amendment violation due to the strip search and denied the motion to dismiss on this claim. ${ }^{408}$ The court also determined the school employees were not entitled to qualified immunity because Redding clearly established the "legal contours" of strip searches prior to the search. 409

When schools and their employees conduct strip searches where a school employee searches a student of the opposite sex, this has also been deemed to violate the student's Fourth Amendment privacy rights. In Hotchkiss ex rel. J.T. v. Garno, J.T., the only African-American student at his middle school, alleged that his female principal strip searched him by having him take his pants down to expose his underwear once in sixth grade in a private office in search of a laser pointer and again in seventh grade in the communal teachers' lounge in search of a music player.410 In denying the principal's motion for summary judgment based on qualified immunity, the court determined that J.T.'s allegations constituted a violation of his Fourth Amendment rights, emphasizing that students do not abandon legitimate expectations of privacy at the school door and are not to be treated as prisoners for Fourth Amendment analysis even in the context of the "schools are different" ideology. ${ }^{411}$ The court identified the significant privacy interest that students have in their unclothed bodies and found that the strip search by an adult woman offended J.T.'s reasonable expectation of privacy. 412

From there, the court determined that this right was clearly established based on an application of a pre-Redding Sixth Circuit decision that had analogously stated almost thirty years prior: "[i]t does not require a constitutional scholar to conclude that a nude search of a thirteen-year-old child is an invasion of constitutional rights of some magnitude. More than that: it is a violation of any known principle of human decency." 413 That the strip search was to the underwear, rather than completely nude, did not affect the court's

405 Id. at 647.

406 Id. at 648 .

407 Id.

408 Id.

409 Id. at 649.

${ }^{410}$ Hotchkiss ex rel. J.T. v. Garno, 883 F. Supp. 2d 719, 722-23, 725-26 (E.D. Mich. 2012).

411 Id. at 731.

412 Id. at $732-33$.

${ }^{413}$ Id. at 733 (quoting Tarter v. Raybuck, 742 F.2d 977, 983 (6th Cir. 1984)). 
conclusion. ${ }^{414}$ The court determined there would be no doubt in the mind of a reasonable government official that the conduct was objectively unreasonable in the light of clearly established constitutional rights. ${ }^{415}$ Consequently, the court concluded that "[a] female school administrator who forces a male middle school student to disrobe to his underwear to search for a stolen music player or laser pointer is not entitled to qualified immunity."416

Finally, when schools and their employees exploit known privacy vulnerabilities of the student through shaming strip searches, they violate the student's Fourth Amendment rights. According to the complaint in Gray v. Great Valley School District, Marykate Gray, a sixteen-year-old eleventh grader, had been assaulted and harassed by students and school staff members, which resulted in a no-contact agreement between the school social worker and Marykate. ${ }^{417}$ After being observed taking an ibuprofen by a teacher, Marykate was removed from class and taken to the assistant principal's office where the social worker confronted her about drug possession. ${ }^{418}$ After a search of her backpack yielded no contraband, Marykate was aggressively patted down by the social worker. ${ }^{419}$ Then, Marykate was taken to the school nurse's office, where the school social worker strip searched her and fondled her breasts during the search under her bra, within view of the assistant principal and within the presence of the nurse. ${ }^{420}$ No contraband was found. ${ }^{421}$ In evaluating the constitutionality of the search, the court found that Marykate was subjected to an unreasonable search in violation of the Fourth Amendment. ${ }^{422}$

Further, the court concluded that the social worker was not entitled to qualified immunity as students' rights in the context of strip searches were clearly established by Redding, which was decided two years before the alleged strip search. ${ }^{423}$ It specifically found that Redding:

was sufficient to put a reasonable school official such as Trimble on notice that strip searching plaintiff-despite knowledge of her emotional vulnerabilities, despite knowledge of the no-contact agreement, without the prior approval of her parents, and without any "distinct elements of justification" to believe that she was hiding contraband underneath her clothing-violated plaintiff's

${ }^{414}$ See id. ("Although this case does not involve a nude search, but rather an alleged order by a female administrator to a middle school male student to strip to his underwear, if true the alleged conduct 'would obviously violate [the Fourth Amendment]."' (alteration in original) (quoting Lewis ex rel. Cornfield v. Consolidated High Sch. Dist. No. 230, 991 F.2d 1316,1320 (7th Cir. 1993))).

415 Id. at 734 .

416 Hotchkiss, 883 F. Supp. 2d at 734-35.

417 Gray v. Great Valley Sch. Dist., 102 F. Supp. 3d 671, 676-77 (E.D. Pa. 2015).

418 Id. at 677.

419 Id.

420 Id. at $677-78$.

421 Id. at 678 .

$422 \mathrm{Id}$. at 685 .

${ }^{423}$ Gray, 102 F. Supp. 3d at 686. 
clearly established right to be free from an unreasonable strip search in violation of the Fourth Amendment. ${ }^{424}$

These cases demonstrate the growing number of courts that will no longer defer to schools' disciplinary authority with regard to strip searches. By denying individuals qualified immunity and relying on Redding to do so, these cases are establishing a precedent that students have a clearly established constitutional right to be free from overly intrusive shaming strip searches. To supplement this point, there have been post-Redding case decisions which evaluate pre-Redding strip searches that premise their grants of qualified immunity on the basis that Redding had not yet clearly established the students' rights. ${ }^{425}$ This implies that future grants of qualified immunity will not be as readily obtained.

Although there have been a few post-Redding strip search cases that have determined the Monell requirements for municipal liability have not been met, ${ }^{426}$ other courts have taken a more expansive view in finding that school entities can have municipal liability for school strip searches. ${ }^{427}$ These expansive views of municipal liability for student strip searches include the recognition that a failure to train could be a Monell policy, and the adoption of the Pembaur approach, which provides that the acts of a government official with final policymaking authority satisfy the requirements for municipal liability. ${ }^{428}$

As to the first approach, in Highhouse the court did not grant the school district's motion to dismiss based on the Monell municipal liability

424 Id.

425 E.g., Wybrow ex rel. V.W. v. DaVinci Acad. of Sci. \& the Arts, No. 1:09-CV127 TS, 2011 WL 4001150, at *6 (D. Utah Sept. 8, 2011) (noting the constitutional rights in a student strip search were not clearly established because the search occurred prior to Redding); S.J. ex rel. S.J. v. Perspectives Charter Sch., 685 F. Supp. 2d 847, 854 (N.D. Ill. 2010) (granting school employees qualified immunity on a claim arising from a pre-Redding strip search because the law regarding school strip searches was not clearly established until Redding).

${ }^{426}$ E.g., Littell v. Hous. Indep. Sch. Dist., 213 F. Supp. 3d 849, 857-58 (S.D. Tex. 2016) (finding student plaintiffs who had allegedly been strip searched by the school nurse had not sufficiently alleged a Monell policy or custom to support the school district's municipal liability); Hayward v. Salem City Bd. of Educ., No. CV 14-5200 (JBS/AMD), 2016 WL 4744132 , at *6 (D.N.J. Sept. 12, 2016) (finding the city could not be held liable for the strip search of a high school student, allegedly conducted within the presence of a city police officer serving as a school resource officer, because the plaintiff could not produce evidence of an official policy or custom authorizing such a search); Hotchkiss ex rel. J.T. v. Garno, 883 F. Supp. 2d 719, 721-22, 737 (E.D. Mich. 2012) (granting school district's motion for summary judgment based on no Monell municipal liability for two alleged strip searches of a student by a principal when the school district policy stated that "[u]nder no circumstances will school staff conduct or be party to a strip-search").

427 See infra text accompanying notes $429-35$.

428 See infra text accompanying notes 429-35; see also supra text accompanying note 221 (discussing Pembaur). 
requirements. ${ }^{429}$ Specifically, the court found the plaintiff had sufficiently alleged a failure to train policy was the causation behind the constitutional injury, as it was alleged that the school district had failed to train its employees on the proper use of searches as part of its disciplinary authority, had failed to train its employees on policies for searches, and had failed to properly discipline employees who were aware of and participated in the constitutional rights violations of students. ${ }^{430}$ These allegations were enough for the court to determine there could be municipal liability for the school district. ${ }^{431}$

As to the second approach, in Marino ex rel. A.M. v. Chester Union Free School District, the court utilized Pembaur to arrive at an expansive view of Monell municipal liability in a $\S 1983$ action, in which two middle school students, thirteen-year-old A.M. and fourteen-year-old E.J., were allegedly strip searched by the principal and by the school nurse prior to the Redding decision. ${ }^{432}$ The court denied the school district's motion for summary judgment that claimed no municipal liability. ${ }^{433}$ It used Pembaur to find the principal was a Monell municipal official vested with final policymaking authority on the daily operations of the school because "while broad rulemaking authority is vested in the school board by law, policymaking authority may not be so strictly limited." $" 434$ Next, it found that the strip searches could plausibly represent school policy, because there was no adopted school board policy on student searches, leaving policy determinations to the principal who had fashioned his own policy based on airport security protocol, which his subordinates were instructed to follow. 435

Although Redding failed to provide comprehensive protections for students' Fourth Amendment rights, ${ }^{436}$ it did establish an important precedent by linking rights-violative student strip searches to the inappropriate and unconstitutional use of shaming as a school disciplinary measure. Further, although the "schools are different" ideology is typically student rights restrictive, ${ }^{437}$ as it has often been employed by courts to determine student constitutional rights have not

${ }^{429}$ See Highhouse v. Wayne Highlands Sch. Dist., 205 F. Supp. 3d 639, 649-50 (M.D. Pa. 2016).

430 Id.

${ }^{431} \mathrm{Id}$.

${ }^{432}$ Marino ex rel. A.M. v. Chester Union Free Sch. Dist., 859 F. Supp. 2d 566, 567 (S.D.N.Y. 2012).

${ }^{433} \mathrm{Id}$. at 570

$434 \mathrm{Id}$. at 569.

$435 \mathrm{Id}$. at 570.

${ }^{436}$ Barry C. Feld, T.L.O. and Redding's Unanswered (Misanswered) Fourth Amendment Questions: Few Rights and Fewer Remedies, 80 MiSS. L.J. 847, 953 (2011) (arguing Redding failed to provide sufficient protections for students' privacy rights).

${ }^{437}$ See Raul R. Calvoz et al., Cyber Bullying and Free Speech: Striking an AgeAppropriate Balance, 61 CLEV.ST.L. REV. 357, 379 (2013) (outlining this ideology); Ronald T. Hyman, Constitutional Issues When Testing Students for Drug Use, A Special Exception, and Telltale Metaphors, 35 J.L. \& EDUC. 1, 10 (2006) (discussing the rights-restrictive nature of the ideology). 
been violated but would have been if exercised by adults in other contexts, ${ }^{438}$ Redding's subtle spin on this ideology may actually prove beneficial to the future preservation of students' Fourth Amendment rights in the context of shaming school strip searches. ${ }^{439}$ By focusing on the inherent differences between adults and children in its determination that Savana's privacy expectation was reasonable through comparing it to the consistent experiences of other similarly searched schoolchildren, whose "adolescent vulnerability intensifies the patent intrusiveness of the exposure," 440 the Court linked shaming punishments in the context of strip searches of children to constitutional violations. ${ }^{441}$ Although there have been some post-Redding strip search cases that have granted qualified immunity for the searching school officials, ${ }^{442}$ the correct constitutional approach has been in those cases that found inapposite based on this shaming link articulated in Redding. ${ }^{443}$

This link has become a central analytical aspect of the growing body of $\S 1983$ case law that has determined strip searches violate students' Fourth Amendment rights and searching officials are not protected by qualified immunity for these shaming sanctions. This line of case law that clearly establishes students' Fourth Amendment rights in the context of invasive strip searches, even as circumscribed as these rights are in schools, ${ }^{444}$ should deter schools and their employees from their use. Awareness of the potential liability that incurs from school strip searches and of their rights-violative nature should

438 Steven G. Gey, The Brandenburg Paradigm and Other First Amendments, 12 U. PA. J. CONST. L. 971, 1039-40 (2010) (showing how the "schools are different" ideology has been used to find that public school students have more limited speech rights than adults outside of schools); Matthew Lynch, Note, Mere Platitudes: The "Domino Effect" of SchoolSearch Cases on the Fourth Amendment Rights of Every American, 91 IOWA L. REV. 781, 807 (2006) (noting how the Supreme Court has employed this ideology in its Fourth Amendment jurisprudence to determine that public school students have more limited privacy rights than adults outside of schools).

${ }^{439}$ See Katz \& Mazzone, supra note 51, at 382 (identifying an important contribution of Redding as the Court's clarity that student strip searches are extraordinary intrusions that should be employed only in extreme circumstances).

${ }^{440}$ Safford Unified Sch. Dist. \#1 v. Redding, 557 U.S. 364, 375 (2009).

441 See Chiang, supra note 136, at 636 (discussing the Court's acknowledgment of the inherent difference between searching adults and students as a central basis for finding the strip search unconstitutional).

${ }^{442}$ See, e.g., Sandidge ex rel. S.S. v. Turner Unified Sch. Dist. \# 202, No. 12-CV-02346CM, 2012 WL 6561525, at *4 (D. Kan. Dec. 14, 2012) (granting the individual defendant qualified immunity for a school strip search because Redding did not "clearly establish[] that a student-informant's tip that she had seen plaintiff put marijuana or marijuana paraphernalia in her bra earlier that day [was] insufficient to warrant reasonable suspicion to search plaintiff's bra").

443 See supra text accompanying notes 431-37.

${ }^{444}$ Mitchell, supra note 26 , at 296 ("[S]tudents do not enjoy the full panoply of the constitution's protections ...."). 
motivate schools, teachers, and administrators to no longer impose them as the inherently shaming punishments they are..$^{445}$

\section{A Conclusion on the Constitutional Critique of School Shaming}

\section{Punishments}

Even though the Supreme Court and federal courts have engaged in a "modern trend of wide deference to the educators' interest in controlling the school environment," "446 which has given rise to one view that judicial "odes to the rights of ... students are illusory platitudes," 447 there are actually limits to such deference when school discipline becomes an abuse of authority. ${ }^{448}$ The imposition of school shaming punishments, like compelled apologies and strip searches, has the significant potential to extend beyond those deferential limits and to result in liability for both schools and their actors for violations of students' First and Fourth Amendment rights. Consequently, these cases should serve as precedent for schools, teachers, and administrators to end the use of shaming punishments to avoid liability and to ensure they are not violating the constitutional rights of their students. There is hope for the preservation of students' speech and privacy rights through the abolition of these shaming sanctions in American schools. ${ }^{449}$

\section{CONCLUSION}

The time has come to end shaming punishments in schools. "The schoolroom is the first opportunity most citizens have to experience the power of government. ... The values they learn there, they take with them in life." The values that are being taught via school shaming punishments to the punished student and the school community are purely retributive, immensely

${ }^{445}$ See Donahoe, supra note 205, at 1169 (discussing how schools should educate their employees about the rights-violative nature of strip searches to promote a safe learning environment).

${ }^{446}$ Bernard James \& Joanne E.K. Larson, The Doctrine of Deference: Shifting Constitutional Presumptions and the Supreme Court's Restatement of Student Rights After Board of Education v. Earls, 56 S.C. L. REV. 1, 11 (2004).

${ }^{447}$ Scott A. Moss, Reluctant Judicial Factfinding: When Minimalism and Judicial Modesty Go Too Far, 32 Seattle U. L. Rev. 549, 559 (2009).

448 See James \& Larson, supra note 446, at 90 ("The Earls model of deference effectively limits the judicial function to watching for evidence of anomaly and abuse of authority ....").

${ }^{4} 49$ See James S. Liebman, Desegregating Politics: "All-Out" School Desegregation Explained, 90 CoLUM. L. REV. 1463, 1641 (1990) ("We need not be totally despondent, however, for if we had to choose a single sphere of political concern in which to accomplish the most political reform by applying a thoroughly reconstructive remedy, education almost certainly would be that sphere.").

${ }^{450}$ New Jersey v. T.L.O., 469 U.S. 325, 385-86 (1985) (Stevens, J., concurring in part and dissenting in part). 
harmful, and potentially debilitating, ${ }^{451}$ like those imposed by exclusionary and corporal punishments. ${ }^{452}$ These are not the norms schoolchildren should be internalizing, ${ }^{453}$ and their inefficacy and harm provide an independent basis for the cessation of shaming punishments in schools. ${ }^{454}$

If this inefficacy and harm analysis does not provide enough persuasion for schools, teachers, and administrators to abandon shaming punishments, the specter of liability for their imposition should do so. ${ }^{455}$ Student rights in schools are certainly circumscribed. ${ }^{456}$ Schools and their actors are given considerable deference in disciplinary authority by courts. ${ }^{457}$ However, there is a limit to this authority, and this limit can be breached by constitutional-rights-violative school shaming punishments. These punishments can and should give rise to monetary, declaratory, and injunctive relief when schools and their actors violate students' First or Fourth Amendment rights. ${ }^{458}$ Awareness of the constitutional violations and potential liability that result from school shaming punishments should provide additional sway to educators to no longer inflict them. ${ }^{459}$

451 See Alec Walen, A Punitive Precondition for Preventive Detention: Lost Status as a Foundation for a Lost Immunity, 48 SAN DIEGO L. REV. 1229, 1262 (2011) (labeling shaming punishments as retributive, "needlessly cruel[,] and counterproductive").

452 See Susan H. Bitensky, Section 1983: Agent of Peace or Vehicle of Violence Against Children?, 54 OKLA. L. REV. 333, 363-65 (2001) (discussing the extensive harms of child corporal punishments); Feld, supra note 436, at 892-94 (discussing the myriad harms of school exclusionary punishments).

${ }^{453}$ See Paul H. Robinson \& John M. Darley, Intuitions of Justice: Implications for Criminal Law and Justice Policy, 81 S. CAL. L. REV. 1, 20 (2007) (discussing the signaling nature of an individual who presently obeys social norms that he or she will be a cooperative participant in future social interactions as these norms are fundamentally self-beneficial).

${ }^{454}$ See Anita L. Allen, Lecture, Privacy Isn't Everything: Accountability as a Personal and Social Good, 54 ALA. L. REV. 1375, 1385 (2003) ("People who harm children should be accountable for the wrong they do.").

455 Ingraham v. Wright, 430 U.S. 651, 678 (1977) (finding school authorities will not likely inflict unnecessary or excessive punishment when they might be sued for it).

456 See, e.g., Homer H. Clark, Jr., David C. Baum Memorial Lecture: Children and the Constitution, 1992 U. ILL. L. REV. 1, 31 (1992) (discussing the irony that, despite the Supreme Court's rhetoric, it has done little to recognize schoolchildren's constitutional rights).

${ }^{457}$ See, e.g., New Jersey v. T.L.O., 469 U.S. 325, 339-40 (1985) (finding the preservation of order and discipline in the school environment justifies the circumscription of schoolchildren's constitutional rights).

458 See supra Part III.B.2-3.

${ }^{459}$ See Karlan, supra note 206, at 1914 ("[T] he overarching purpose of constitutional law is to deter or prevent deprivations of individuals' rights, and not simply to induce the government to internalize their costs or to compensate individuals who suffer them after the fact."). 
So, what, then, would be a preferred method of school discipline ${ }^{460}$ An extended recommendation of such an alternative is beyond the scope of this Article, given the "intractable puzzle of what method ... might be the best means." 461 However, a focal point for this emerging dialogue should be that "environments can be altered not just to stop conduct, but also to facilitate better decision-making." 462 As schools abandon shaming, they should adopt alternative measures to shape student behavior in positive, rather than stigmatizing, ways, ${ }^{463}$ like positive behavioral interventions and supports, ${ }^{464}$ that are sensitive to and aware of the developmental maturity and self-identity of children. ${ }^{465}$

Although the dialogue should be open as to better alternatives, the question of whether schools should utilize shaming penalties should be closed. These punishments harm individual students and create broader negative collateral consequences. These punishments can violate students' constitutional rights and expose schools to liability. Consequently, shaming punishments should be eliminated as disciplinary measures in $\mathrm{K}-12$ schools. "Schools cannot expect their students to learn the lessons of good citizenship when the school authorities themselves disregard the fundamental principles underpinning our constitutional freedoms."466 Therefore, school entities and actors, schoolchildren, and school communities must no longer play the unconstitutional roles required in the degradation ceremonies that are inherent in shaming punishments.

${ }^{460}$ This preference in discipline is an important consideration that merits further discussion. See Robinson \& Darley, supra note 453, at 18 (arguing that reform of a punishment system is an arduous process).

461 Massaro, supra note 119 , at 649.

462 Ryan Calo, Essay, Code, Nudge, or Notice?, 99 IOWA L. REv. 773, 798 (2014).

${ }^{463}$ See Jason P. Nance, Over-Disciplining Students, Racial Bias, and the School-toPrison Pipeline, 50 U. Rich. L. REV. 1063, 1070 (2016) ("Schools must also replace... harsh disciplinary measures with evidence-based practices that create safe, positive learning climates.").

${ }^{464}$ See Brown, supra note 36, at 950 (arguing school discipline can only be positively reformed through a comprehensive approach that includes revision of harmful policies, increasing disciplinary education, and systematic data collection to isolate and identify persistent inequities).

${ }^{465}$ See id. at 965-71 (advocating for reform of disciplinary practices in schools to implement constitutional alternatives that are developmentally appropriate for children); Janel A. George, Stereotype and School Pushout: Race, Gender, and Discipline Disparities, 68 ARK. L. REv. 101, 127 (2015) (discussing school disciplinary alternatives that are "gender-responsive, trauma-sensitive, and culturally competent").

466 Doe ex rel. Doe v. Renfrow, 451 U.S. 1022, 1027-28 (1981) (Brennan, J., dissenting from denial of certiorari). 
